\title{
DAMAGE AND INTENSITIES IN THE MAGNITUDE 7.81931 HAWKE'S BAY, NEW ZEALAND, EARTHQUAKE
}

\author{
David J. Dowrick ${ }^{1}$
}

\begin{abstract}
SUMMARY
This paper is the result of a study of the shallow $M_{W}=7.8$ Hawke's Bay earthquake which occurred in the North Island of New Zealand, 2 February 1931(UT), and which was the final spur to the production of the first earthquake loadings code in New Zealand issued in 1935. This earthquake was a direct hit on two provincial towns (Napier and Hastings) and was the most damaging in New Zealand's history, causing the most casualties, major fires, and much damage to the built and natural environments. It gives the first overall description of the damage (to the buildings and lifelines) in this major event in modern earthquake engineering terms, and presents the first intensity map for the event determined directly in the Modified Mercalli (MM) scale. The zone which experienced the highest intensity (MM10) was confined to a modest area of onshore land (about $300 \mathrm{~km}^{2}$ ) above the centre of the rupture surface.
\end{abstract}

\section{INTRODUCTION}

The Hawke's Bay earthquake originated at 10.46 am on 3 February 1931 ( 2 Feb 22.46 UT). Its magnitude at $M_{W}=M_{S}=$ 7.8 [1], was the same as that of the 1929 Murchison (Buller) earthquake, $M_{W}$ 7.7, $M_{S} 7.8[1,2]$, making these two earthquakes the largest in New Zealand since the 1855 magnitude 8+ Wairarapa earthquake. In deriving an elastic dislocation model from changes in ground levels caused by the Hawke's Bay event, and measured shortly afterwards, Haines and Darby [3] estimated its seismic moment from which $M_{W}=$ 7.7-7.8 was obtained. It was predominantly a thrust event with a ratio of reverse to strike-slip component of c. 1.0 [3]. The source was large and extended from about $30 \mathrm{~km}$ deep, at the subduction interface, the primary rupture probably extending to within about $5 \mathrm{~km}$ of the surface. As is evident from the changes in levels shown in Figure 1, the primary rupture did not reach the surface. The extension to the surface of the model of the rupture plane is the line of zero vertical displacement (separating uplift and subsidence), shown on Figure 1 (A.J.Haines, pers. comm., 1996), and the short surface scarps, although up to $4.5 \mathrm{~m}$ high [4], were evidently secondary ruptures.

Haines and Darby's [3] preferred rupture model (shown in plan on Figure 2) has a rupture length of $80 \mathrm{~km}$, with Napier at its centre and Hastings nearby. To the northeast of Napier the rupture (model) extended $40 \mathrm{~km}$ under the sea, (about halfway to Wairoa), while to the southwest it extended to $40 \mathrm{~km}$ almost to the village of Pukehou (Te Aute College). While epicentre determinations of the 1931 era were not able to be very accurate, the contemporary epicentre of $39^{\circ} 20^{\prime} \mathrm{S}, 176^{\circ} 40^{\prime} \mathrm{E}$, is $30 \mathrm{~km}$ from the present day estimate of $39.3^{\circ} \mathrm{S}, 177.0^{\circ} \mathrm{E}$, which is seen in Figure 2 to fit the rupture model well.

\footnotetext{
${ }^{1}$ Institute of Geological \& Nuclear Sciences, Lower Hutt (Fellow)
}

This event is New Zealand's most important past earthquake in engineering and risk terms, both because of its large magnitude and also because it caused more damage to the built environment and more human casualties than any other earthquake in New Zealand history. Estimated total costs of material damage in the four most damaging New Zealand earthquakes this century are given in Table 1, showing the Hawke's Bay earthquake to have been 1.6 times more costly in material damage terms than the next worst earthquake. Hence, a modern view of the damage and intensities caused by this event is likely to be instructive and influential in earthquake engineering, hazard and risk terms. This has proved to be the case for the recent similar study of the $M_{S} 7.8\left(M_{W} 7.7\right) 1929$ Murchison earthquake [2]. Also, in a recent study of the Hawke's Bay earthquake which concentrated on damage to houses in Napier [5], important findings were made including major ones relating to microzoning in very strong shaking.

The only other significant engineering studies of damage in the Hawke's Bay earthquake were the contemporary papers on buildings by Dixon [6,7] and Brodie and Harris [8], Furkert's [9] discussion of damage which concentrated mainly on civil engineering aspects, particularly bridges, and Robinson and Benjamin's [10] account of damage and repairs to the electrical supply system. Various comments on damage to structures and the environment are given in an unpublished report of a reconnaissance trip by H. F. Baird [11]. The most wideranging review of damage to the built environment is that given by Callaghan [12], an excellent factual but non-technical account. 


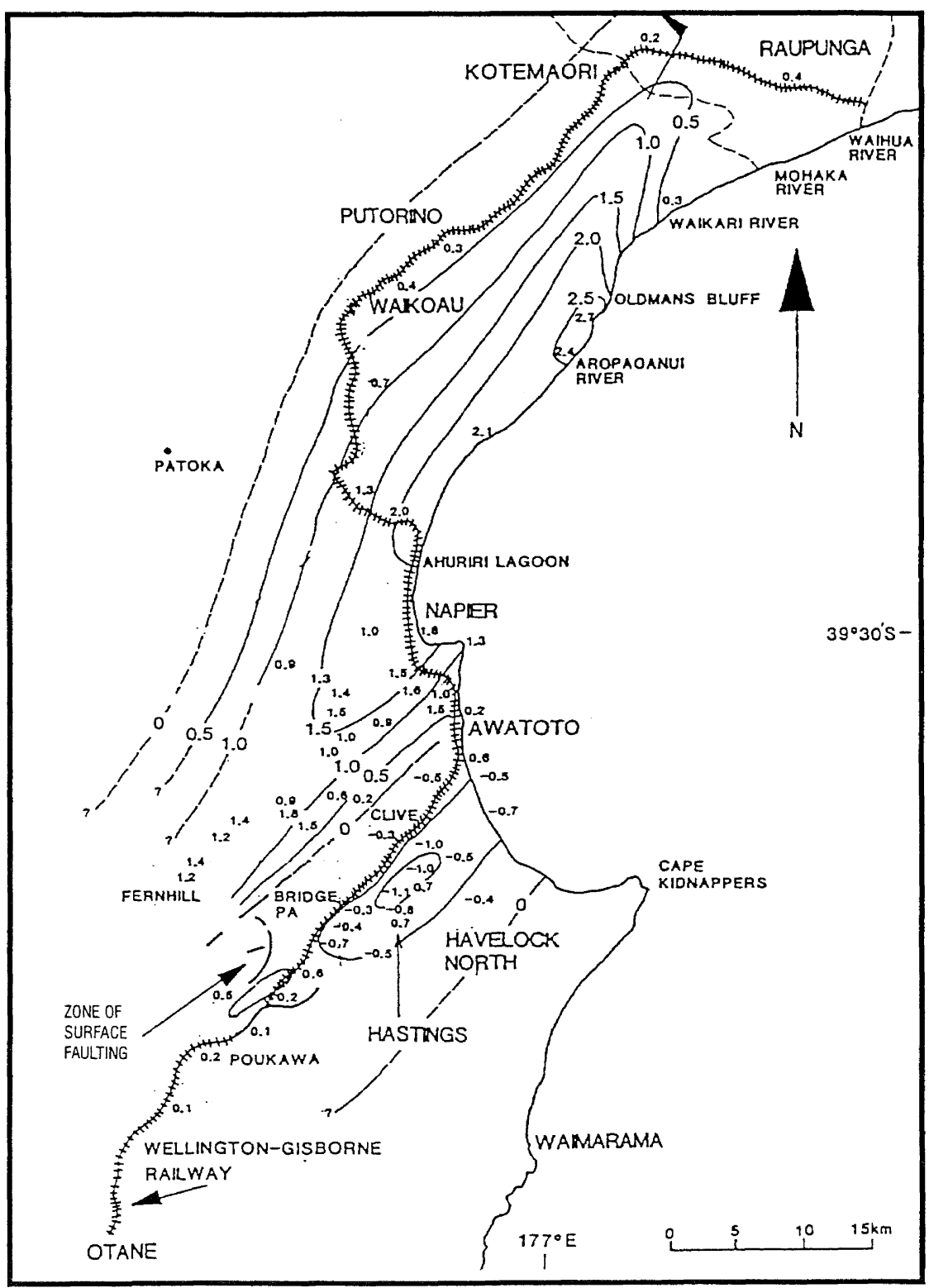

Figure 1: Map of contours of height changes (m) and surface faulting in the 1931 Hawke's Bay earthquake adapted from Hull [4]).

Table 1: Material damage costs in New Zealand's four most damaging earthquakes this century.

\begin{tabular}{|c|c|c|c|c|c|c|}
\hline \multirow[b]{2}{*}{ Date (UT) } & \multicolumn{2}{|c|}{ Epicentre } & \multirow{2}{*}{$\begin{array}{c}\mathrm{h}_{\mathrm{C}} \\
(\mathrm{km})\end{array}$} & \multirow{2}{*}{$\begin{array}{l}\text { Magnitude } \\
\mathrm{M}_{\mathrm{W}}\end{array}$} & \multirow{2}{*}{$\begin{array}{l}\text { Damage Cost } \\
\text { NZ\$ million } \\
\text { (1998 Values) }\end{array}$} & \multirow[b]{2}{*}{ Location } \\
\hline & os & ${ }^{o} \mathrm{E}$ & & & & \\
\hline 19290616 & 41.7 & 172.2 & 9 & 7.7 & c. 136 & Murchison, South Is \\
\hline 19310202 & 39.3 & 177.0 & 17 & 7.8 & c. 512 & Hawke's Bay, North Is \\
\hline 19680523 & 41.8 & 172.0 & 10 & 7.2 & 39 & Inangahua, South Is \\
\hline 19870302 & 37.9 & 176.8 & 4 & 6.5 & 315 & Edgecumbe, North Is \\
\hline
\end{tabular}

Notes: $\quad h_{C}$ is depth to centroid of fault rupture $\mathrm{M}_{\mathrm{w}}$ values from Reference 1 . 


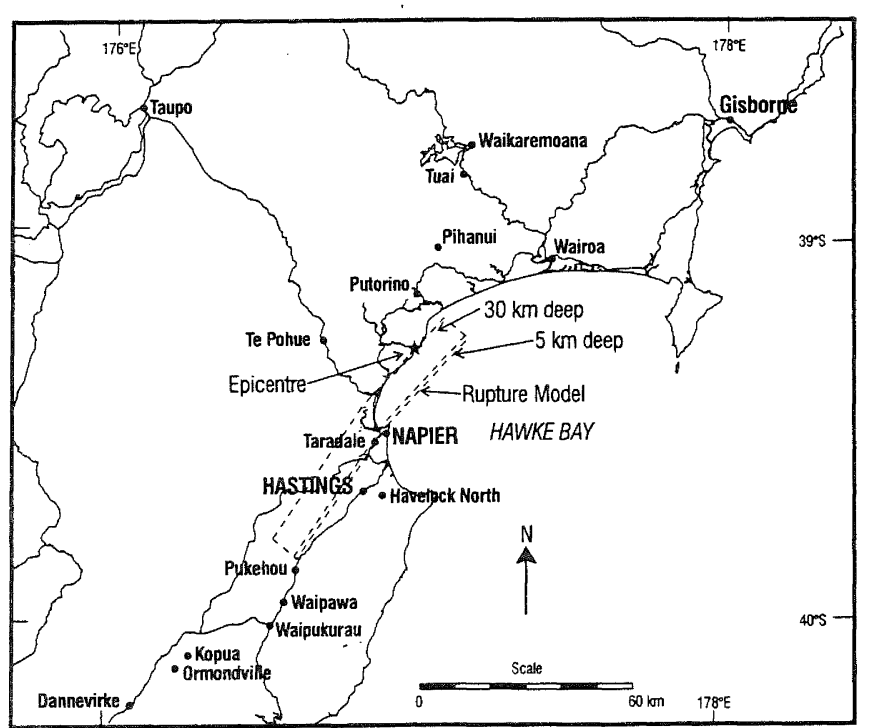

Figure 2: $\quad$ Map showing preferred elastic deformation model of the uplift of Haines and Darby [3] and locations mentioned in the text.

The Modified Mercalli (MM) intensities experienced in this earthquake have not previously been properly determined. At the time of the earthquake the Rossi-Forel (RF) intensity scale was in use in New Zealand, and RF intensities for this event were assigned from the felt reports sent in to the New Zealand Seismological Observatory immediately after the earthquake. In 1933 Adams et. al. [13] published a Rossi-Forel isoseismal map presumably based on these felt reports. In much more recent times (the 1970's approximately), using Richter's [14] approximate conversions of these intensities to the MM scale, Eiby prepared a preliminary MM intensity map which he appropriately did not publish, although it has appeared with cautionary remarks in the recently published atlas of New Zealand intensity maps [15]. As discussed by the present author [2], in relation to the Murchison earthquake, both the $\mathrm{RF}$ scale and the published conversions from RF to MM intensity are very poor.

Thus this study is the first modern overview of the damage to the built environment and the intensities in this important earthquake. With the recent revisions of the New Zealand version of the Modified Mercalli intensity scale [16,17], and the current need for reliable intensity maps and isoseimal modeling of large earthquakes for planning and insurance purposes, this present study (like that of the 1929 Murchison earthquake) is particularly timely.

\section{DAMAGE OVERVIEW}

The damage and human casualties in this earthquake were so severe that within less than three weeks of its occurrence a new Building Regulations Committee was formed, and eventually (in 1935) New Zealand's first earthquake code was issued. This earthquake caused Modified Mercalli intensities of VIII (MM8) and greater over a distance of approximately $190 \mathrm{~km}$, from Waipukurau in the southwest almost to Gisborne in the northeast. The natural environment suffered major damage and great permanent changes, with substantial landslides $[18,19$, $20]$ mainly north of Napier, and over $2 \mathrm{~m}$ of uplift [3,4] west of the extrapolation to the surface of the rupture plane (Figure 2). This raised much of the bed of the large Ahuriri Lagoon (Figure 3), with an area of 30 square kilometres, above high tide level. Liquefaction effects were noted in various widely scattered locations [21], while on the soft ground in Napier 10 percent of house sites were reported [5] to have ground damage, i.e. liquefaction. The earthquake was the most damaging to the built environment in New Zealand since the substantive beginning of European settlement c. 1840. The total cost of material damage was approximately NZ $\$ 512$ million compared with the next worst, the 1987 Edgecumbe earthquake, which was NZ $\$ 315$ million, both costs being given in 1998 value terms (Table 1).

As seen in Figure 2, the town of Napier straddled, and Hastings was $5 \mathrm{~km}$ from, the vertical projection of the top of the primary rupture surface. The Department of Statistics estimates for 30 April 1931 gave populations for Napier and Hastings of 16,200 and 12,000 respectively. Several other small communities were in the same locality. The total population within the MM8 isoseismal was about 65,000 , of whom 55 percent lived in seven towns or villages of more than 1000 people. With this sizeable population and many brittle non-domestic buildings in the zone of strong shaking, high damage and many casualties were inevitable. The official records show that 256 people were killed and about 400 people required in-patient hospital care for injuries. These casualty figures far exceed those of any other New Zealand earthquake; there were 17 deaths in the 1929 Murchison earthquake [2] and in the 1987 Edgecumbe earthquake there was only one casualty (a broken arm). Considering that the latter earthquake caused about $60 \%$ of the damage of the Hawke's Bay earthquake, the casualty rate was more than 400 times greater per unit damage cost in the Hawke's Bay earthquake. As both events occurred during the middle of the day on a weekday, this very large difference is attributed to the following:

- The introduction of earthquake design codes after the Hawke's Bay earthquake (ie. in 1935), and the absence of unreinforced masonry in the Edgecumbe epicentral area. Well over 100 buildings collapsed (lost $\geq 50 \%$ of their volume) in Hawke's Bay, while less than five collapsed in the Edgecumbe earthquake.

- The higher intensity at the centre of the Hawke's Bay earthquake (MM10 compared to MM9).

- $\quad$ The alarm caused by the Edgecumbe foreshock, seven minutes before the mainshock caused many dangerous locations to be evacuated at the time of the main shock.

- The higher population within the MM9 isoseismal in the 1931 event $(43,800)$ compared with 10,900 in the 1987 event. 


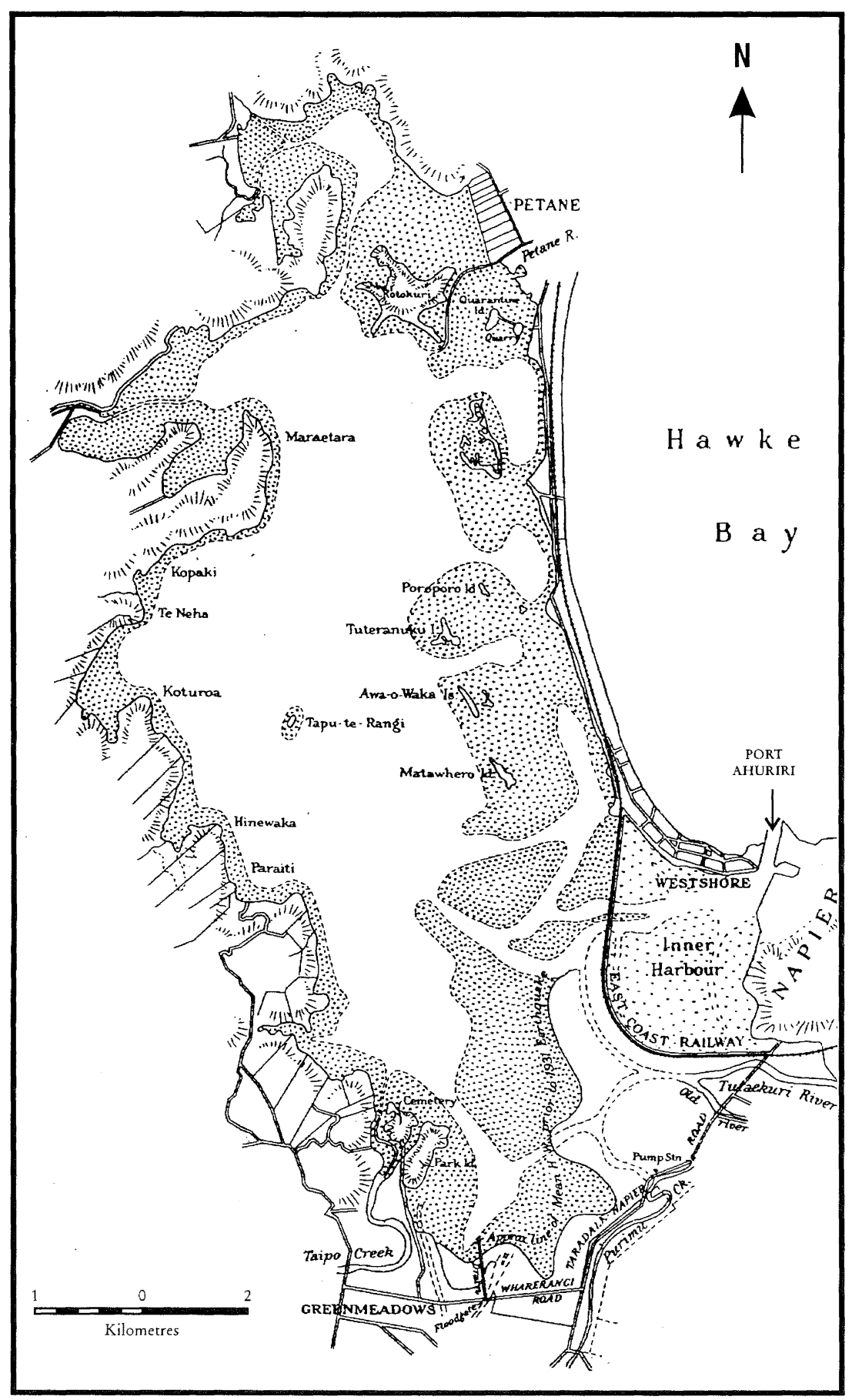

Figure 3: $\quad$ Map showing uplifted floor of Ahuriri Lagoon (Napier Harbour) (after Marshall [19]).

\section{DAMAGE TO ROADS, RAILWAYS, BRIDGES AND WHARVES}

Much damage was done to roads, railways, bridges and wharves in the Hawke's Bay earthquake. This damage mostly occurred where the intensity of ground shaking was MM9 or greater, with the notable exception of the road bridge in Wairoa (due to liquefaction) where the intensity was MM8.
The damage to the roads and railways was dramatic on the man-made embankments across the harbour in the near-fault zone around Napier, as seen in Figure 4 and other contemporary photographs, e.g. References 22-24. According to Callaghan [12] the Napier-Wairoa road was blocked in many places by slips in road cuttings, while the Napier-Taupo road was much less affected, being open again within two or three days. In addition, embankment approaches to bridges subsided badly and spread laterally in many instances. The main road 
south from Napier was negotiable by vehicles with occasional difficulty.

Regarding railways, Callaghan [12] observed that:

"The railway-line from the south was workable as far as Kopua Viaduct, which is located north of Ormondville, but between that point and Hastings it was badly damaged, the rails being bent and twisted in many parts, embankments having slumped, bridge approaches having been destroyed, and the bridges themselves fractured. Wherever the railway traversed swampy ground the rails were badly bent, so that no traffic was possible. Between Hastings and Napier the damage was not so extensive.

On the railway-line north of Napier, across the West Shore Bridge, and northwards, and also to Port Ahuriri, a good deal of fracturing took place, the nature of the damage being similar to that seen farther south."

The train service from Wellington to Hastings was restored by the afternoon of 5 February, and the Hastings to Napier service was restored the following day, albeit at slow speeds initially.

Damage to some of the road and rail bridge structures has been described in contemporary terms by Furkert [9], who discussed the nature of the damage to a number of road and railway bridges. Photographs of the notable incidents appear in various publications [22-24], including the Havelock North - Hastings road bridge (Figure 5). Another example is the Wairoa road bridge (Figure 6) which lost two adjacent 60 foot $(18.3 \mathrm{~m})$ spans at the southern end. According to Smith [25], the northern bank of the river slumped towards deep water, "with the result that the bottom of the nearest pier was pushed out from the bank". From Figure 6 and other photographs the pier that displaced the most was the third from the north, and as it was fully in the river it may also have been affected by liquefaction.

Ground shaking and liquefaction apparently combined to cause severe damage to wharves at Napier as seen in various photographs [22,23], an example of which is given here (Figure 7). In the Remark Book of H.M.S. "Veronica" (which helped in search and rescue operations), the damage was summarised thus:

(1) All wharves in the Inner Harbour (Figures 3 and 7) are severely damaged and are at present unserviceable.

(2) The breakwater is only slightly damaged.

(3) Breakwater wharf is damaged beyond repair.

(4) Glasgow wharf has suffered considerable damage, but is not beyond repair.

Furkert [9] remarks on the apparent severity of the horizontal soil pressures that must have acted on quay structures. $\mathrm{He}$ notes that "The main reinforced-concrete wharf, approximately 600 feet $[180 \mathrm{~m}]$ long and 80 feet $[24 \mathrm{~m}]$ wide, standing in approximately 24 feet $[7 \mathrm{~m}]$ of water, had nearly every pile broken where the bracing of the under structure connected with the piles. Practically no damage was done to the deck or bracing." In the above quotation Furkert was evidently referring to Glasgow wharf which was a finger wharf coming off the breakwater, an entirely concrete structure without rock or hydraulic fill. As might be expected, some of the worst damage was experienced by the wharf structures built parallel to and supporting land areas which were generally reclamations, e.g. as shown in Figure 7.

\section{DAMAGE TO UTULITIES}

The damage in the Hawke's Bay earthquake to public utilities (namely electricity, water supply, sewerage, gas supply and telephone systems) was very severe in the near source region. For example, according to Grayland [26], in Napier repairs were required to 6 miles $(9.6 \mathrm{~km})$ of 10 foot $(3 \mathrm{~m})$ diameter storm-water drains, 8 miles $(13 \mathrm{~km})$ of kerbing and channeling, and 25 miles $(40 \mathrm{~km})$ of drains. Also 6.8 miles $(11 \mathrm{~km})$ of underground cables were laid.

\section{Water Supply Systems}

Napier suffered the worst water supply damage of any urban area effected. Brodie and Harris [8] noted that: "In Napier the water-supply was seriously interrupted by the first shock, and the lack of water greatly hindered fire-fighting. Cast-iron mains were badly fractured at junctions, and at joints the lead packings were disturbed, allowing extensive leakage."

The main reservoir on Bluff Hill was not badly fractured, but drained quickly when the mains fractured. Above this tank was a 10,000 gallon tank on a tower for supplying Bluff Hill residents. This tower collapsed. The brick pump house for supplying the reservoir collapsed. Full restoration of the Napier water supply took many months to achieve.

In Hastings the water mains sustained very little damage apart from subsidence at bridges and fillings. A section of the main supply pipe to Hastings supported by the Havelock North bridge was lost when that structure collapsed (Figure 5). Water supply was apparently generally restored within a day or two [Ref. 22, p. 112]. Artesian water from Hastings was temporarily pumped to the Havelock Hills reservoir to give more head. Hastings water supply was maintained by pumping artesian water directly into the mains. The pipe bridge was reinstated on the 10th of February, seven days after the main shock. The mains pressure was quite satisfactory at 100 lb/sq.in. [ $690 \mathrm{kPa}$ ] by 9 th February.

In Wairoa where the intensity was MM8, there was damage to the water mains with an improvised water truck in service [Ref. 23, p.96]. The supply was still down on the 8th of February. In Waipukurau, also with intensity MM8, the reservoir and reticulation were undamaged, but the water supply was temporarily interrupted because the suction pipe was blocked and the pump was out of commission. In Gisborne, at intensity MM7, the only damage consisted of several leaks in the reticulation. 


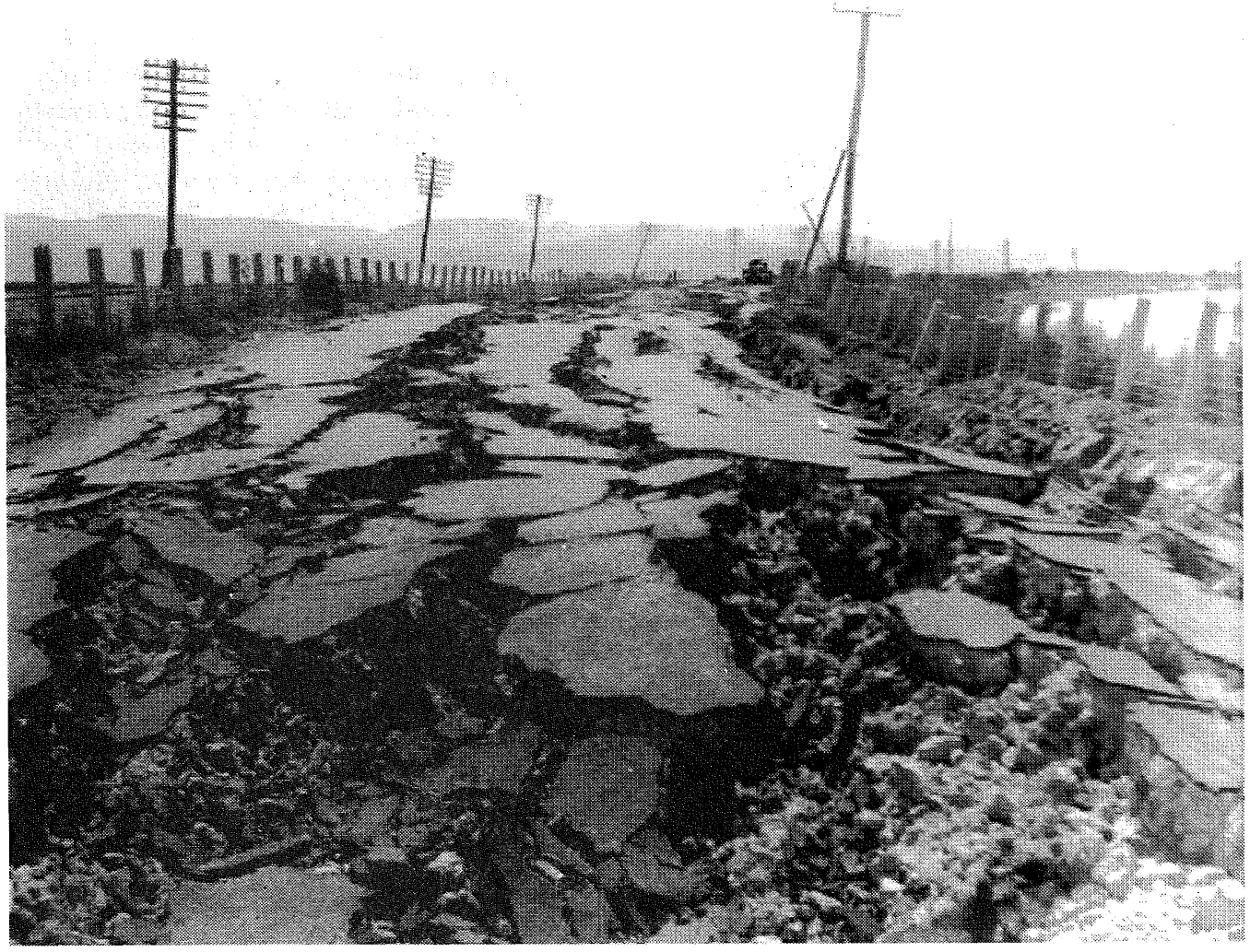

Figure 4: $\quad$ Photograph showing severe lateral spreading of embankment of road across Napier Harbour. (Courtesy of the Alexander Turnbull Library, Tyndall Collection, Wellington).

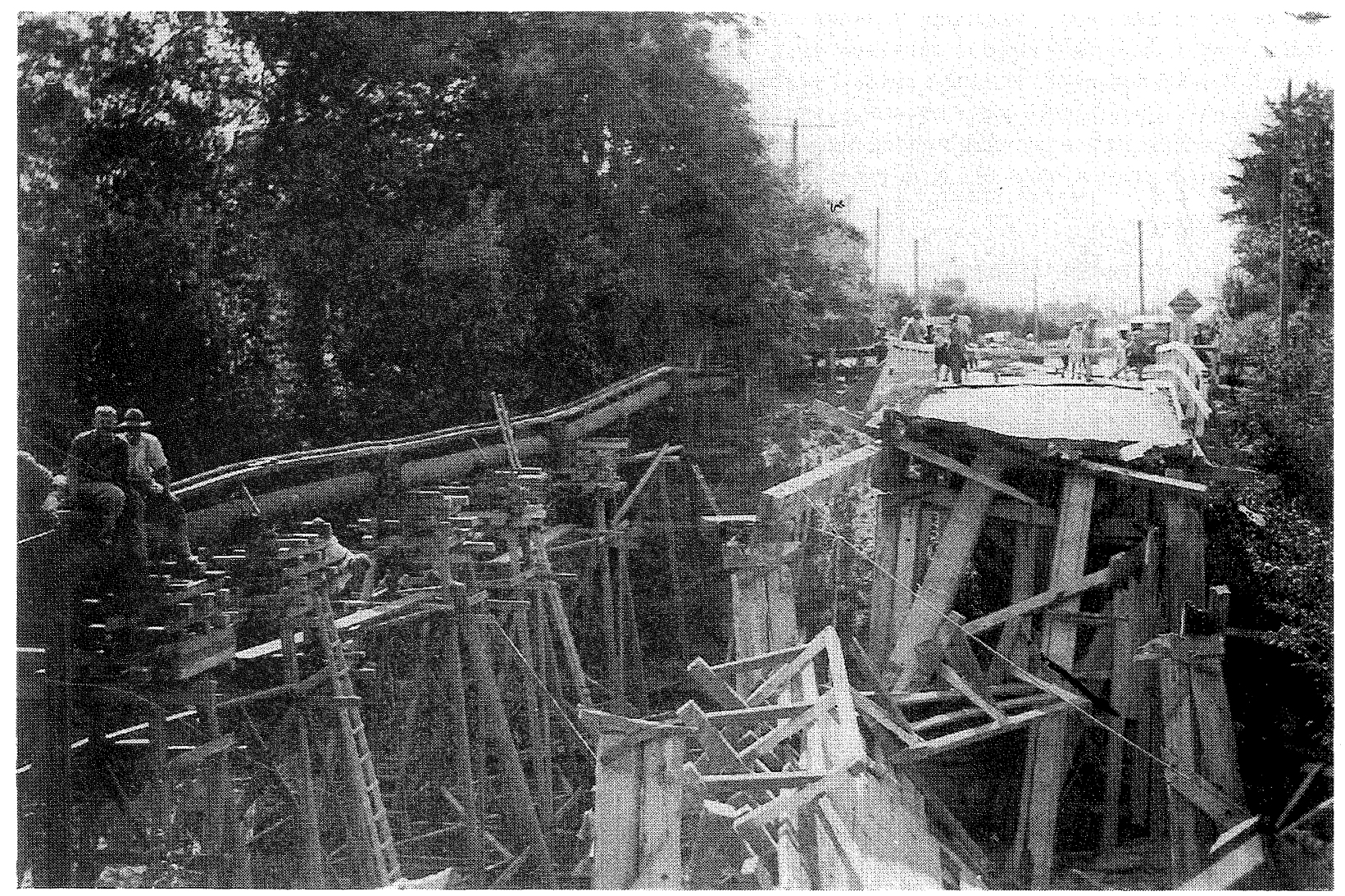

Figure 5: Photograph showing destruction of Hastings-Havelock North road bridge and temporary restoration of water main. (Courtesy of the Alexander Turnbull Library, P.A. Ashcroft Collection, Wellington). 


\section{Sewerage Systems}

In Napier, as well as damage to the water supply, according to Brodie and Harris [8] "The sewage system was also badly damaged. In some lengths laid on silt at a depth of $5 \mathrm{ft}$. to $6 \mathrm{ft}$. [1.5-1.8 m], earthenware pipes, whether on a concrete bed or not, were badly fractured. Concrete pipes without a concrete bed were much less damaged." According to Conly [Ref. 23, p.158] it took many months to reinstate the sewerage reticulation system fully in Napier. Fussell [27] reports that "the winter of 1931 was to be one of ditches criss-crossing roads and footpaths as the work proceeded." Damage to householder's drains in Napier was also considerable. From a database on costs of repairs to houses [5], it was found that house drains were damaged to some extent in about 30 percent of cases overall, while for houses situated on the soft (redrained) land, drains were damaged in most cases. The cost of drain repairs was about 20 percent of the total cost of damage to houses [5].

In Hastings the sewerage system was laid in concrete and glazed earthenware pipes at depths varying from a few feet to 12 feet $(3.7 \mathrm{~m})[8]$ and suffered little damage. The "Evening Post" newspaper reported on 9 February that Hastings sewerage was working quite well, with only one small substation to be repaired.

Apparently the sewerage systems in other towns were effectively undamaged.

\section{Gas Supply Systems}

The gas supply system in Napier suffered badly. The Napier Gas Company's plant was much damaged, though the buildings were mainly standing. The mains, according to the "Evening Post", 10 February, needed to be uncovered before they could again be put into commission. It was almost two months before the repairs were completed [12]

At Hastings, the gas plant was put out of action though the bursting of the lower section of the manometer. "The Dominion" newspaper reported on 11 February that repairs at the Gas Works should be completed within a fortnight, and the mains would then be tested with special gas. The repairs to the mains were completed within a week [12].

\section{Electricity Supply Systems}

The following notes were derived from the detailed account of Robinson and Benjamin [10] and the complementary one of Callaghan [12].

The main (and nearest) source of electricity for the region of strongest shaking was the Waikaremoana hydro-electric power station, located at Tuai $80 \mathrm{~km} \mathrm{NNE}$ of Napier. While the intensity of shaking there was moderate (MM8), minimal damage was done to the facility. The concrete dam was undamaged, but on the earth dam, some longitudinal and one transverse crack appeared, up to $50 \mathrm{~mm}$ wide and apparently about a metre deep.

The power house building suffered a few minor cracks in the reinforced concrete walls and columns, while its concrete block partitions were more severely cracked.
The power supply in the area surrounding Napier and Hastings was disrupted by a number of factors. A transmission tower on the high voltage line from the Waikaremoana hydro-electric power station fell due to a landslide at Pihanui in hill country about $60 \mathrm{~km}$ NNE of Napier. At Taradale (directly above the top of the modelled fault rupture, Figure 2), the reinforced concrete substation building was badly damaged, three transformers were overturned and the fourth moved out of its rails, breaking all their bushings and oil piping. Regarding the switchgear, very considerable damage was done to the $110 \mathrm{kV}$ air-break switches, isolating switches and post type insulators.

As far as the Hawke's Bay Power Board was concerned, the main damage occurred at the substations, where 14 out of 19 single phase transformers overturned, badly damaging the structures as well as the cases and bushes of the transformers. Callaghan [12] notes also:

"It was found that the main feeder-lines erected with steel poles and towers had suffered very little damage, and that for the most part the worst damage was due to poles which had been canted over out of alignment.

"By Wednesday evening [the day after the main shock], repairs were sufficiently far advanced to make power available from the Mangahao Station for service in connection with the Napier sewage and drainage system.

"Power from Waikaremoana was restored within six days of the earthquake, the work of restoration being greatly facilitated by generous assistance received from Power Boards in neighbouring unaffected areas. By the 6th February it was possible to supply power and light to the hospitals at the Hastings Racecourse and at the Greenmeadows Racecourse, both of which were serving as the main hospitals for the respective towns.

"On the 7th February power was restored to the principal dairying areas, where its use was essential in connection with milking-machines, and about the same time it was also made available to the principal freezing-works at Whakatu, Tomoana, and Pakipaki [all near Hastings].

"Within a month after the earthquake power was available throughout the whole of the area south of Napier, and to some one thousand five hundred houses, whose reticulation had been passed as satisfactory by the Inspectors."

In the Wairoa District (MM8) some power lines were brought down, but the poles generally remained standing. At the Wairoa Substation three of the four transformers jumped their chocks, and suffered damage to gauge glasses, conservator tanks and bushings.

\section{Telegraph System}

The earthquake caused very severe damage to the Post and Telegraph Department's general system. The exchanges in Hastings and Napier were both put completely out of action $[10,12]$, the latter building having been in the fire zone. In addition Callaghan [12] notes:

"Telegraphic communication was cut off north of Waipukurau, and all lines radiating from Napier, Wairoa, and Gisborne 
westward were dislocated.

"The movement of the earthquake was particularly destructive to telegraph-poles, which canted over at alarming angles and in many cases collapsed altogether. Automatic machinery used in connection with the telephone system, was, owing to the severity of the shake in Post and Telegraph offices, put badly out of alignment, and rendered useless.

"Short circuits were exceedingly common, and in many places the wires between the poles became twisted into ropes by the oscillatory movement induced by tremors. Telegraphic communication was cut off within the area between Dannevirke in the south and Gisborne in the north by the first shock, so that it was impossible either to get news from or to the earthquake region, or to communicate by telephone or telegraph between points within the district. The telegraphlines radiating westwards from Hawke's Bay were also put out of commission.

"On the 4th February, at 1.35 a.m., the first telegraphic connection between Hastings and the south was arranged, and twelve hours later a similar connection was made to Napier. Improvements were rapidly effected so that later in the day a quadruplex circuit was in operation as far as Hastings, and two wires were available to Napier in the evening.

"On the 5th February telegraphic communication was established with Auckland via Taupo, the first contact being effected at 11.50 a.m., and by 5 p.m., a duplex set was in operation in this circuit."

\section{DAMAGE TO BUILDINGS}

This large shallow earthquake occurred prior to the introduction in New Zealand of the first earthquake code for buildings, so it is not surprising that considerable damage occurred, especially to brick buildings in the near-source zone. The author has been able to find much information on the construction of buildings and the damage to them, from a variety of sources, i.e. the papers already cited by Dixon $[6,7]$, Brodie and Harris [8], street plans of the Fire Underwriters Association [28] showing buildings and damage in parts of Hastings and Napier, and many photographs, some in books [e.g. 22-24], Ford's collection [29], and the collections held by the Hawke's Bay Museum, in Napier, the Alexander Turnbull Library, and the National Archives, both in Wellington. Mitchell [30] and Furkert [9] also gave overviews of damage to buildings.

The performance of houses in the zone of strongest shaking (MM10) has already been described and quantified in detail in a recent study of Napier by Dowrick et. al. [5], and timber houses were found to be much less damaged than previously thought. Here we concentrate on examining the performance of non-domestic buildings, and do that mainly by looking at the four largest towns which experienced MM8 or more. These towns, with their approximate populations, were Napier $(16,200)$, Hastings $(12,000)$, Wairoa $(2,620)$ and Waipukurau $(1,970)$.

As also found in a study of the 1929 Murchsion earthquake [2], the Hawke's Bay buildings referred to in contemporary reports as "well-built" were reported $[8,9,30]$ to have resisted the earthquake well, despite the fact that these buildings pre-date the first draft of the earliest New Zealand earthquake design codes. However the beginnings of an earthquake resistant design culture in New Zealand pre-date 1931, as evidenced by the publication in 1926 of the book "Earthquakes and building construction" by the prominent New Zealand architectengineer C R Ford. This book does not present a method for designing for horizontal loads. Some engineers and architects had consciously been adopting largely intuitively derived detailing and proportioning measures to counter earthquakes (Guy Natusch, architect, Napier, pers. comm.). The performance of buildings is now discussed according to the type of construction.

\section{Timber Buildings}

Non-domestic buildings built solely of timber performed very well in the zone of strongest shaking (in the Hastings/Napier area). This is evident from all (of the many) contemporary accounts, photographs and still existing buildings. According to Brodie and Harris [8], there were no instances of more than minor damage to well-constructed timber shops. This statement should be qualified by observing that the lack of proper stiffening behind the front windows caused much glass breakage [30] (Figure 8). Apart from this partial "soft-storey" weakness, and cases of inadequate wall bracing, the main defects were found below the ground floor, i.e. damage caused by either lack of sub-floor bracing or inadequate foundations, especially in silty ground.

\section{Brick Buildings}

Many non-domestic buildings throughout the affected area were of brick construction. As is typical of any form of construction subjected to strong shaking [31], the damage to brick buildings varied from total destruction to virtually undamaged. Even in the zone of strongest shaking (Hastings/Napier), some brick buildings were essentially undamaged. Features of brick buildings which Brodie and Harris [8] considered to have caused much of the damage were:

(i) Permitting adjacent buildings of different heights to abut one another.

(ii) Insufficient area of footings, where the subsoil was silt.

(iii) Absence of ties across foundations [in silty ground?].

(iv) Interior timber partitions inadequately fixed to the exterior brick walls (Figure 9(a)).

(v) Poor mortar and inefficient band-course reinforcement (Figure 9(a)).

(vi) Support of heavy roofs on piers or walls too thin to withstand the racking effects produced.

(vii) Heavy brick shop fronts inadequately connected to the rest of the building.

In relation to item (v) above, the good performance of some brick buildings was attributed not only to the use of strong mortar but also to the use of wire-mesh strips used on average at every 9 th or 10th brick course [8]. Thus the presence or absence of such reinforcement should be ascertained as part of the evaluation of unreinforced masonry (URM) "earthquake risk buildings," e.g. when using guidelines such as Reference 32.

Regarding the quality of mortar in brick buildings, Mitchell 


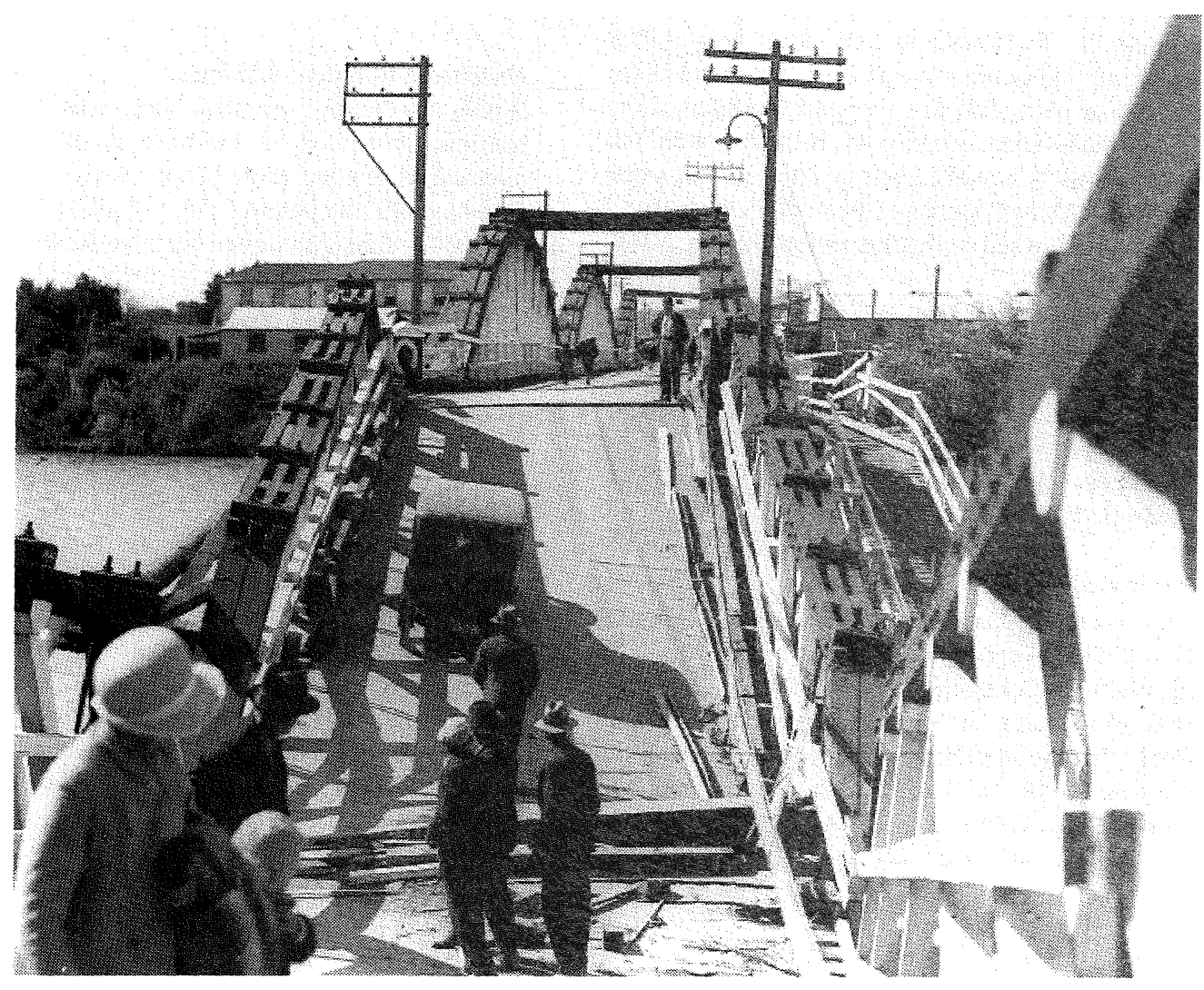

Figure 6: View southwards of main road bridge at Wairoa, showing effect of failure of third pier from north abutment. (Courtesy of New Zealand Herald.)

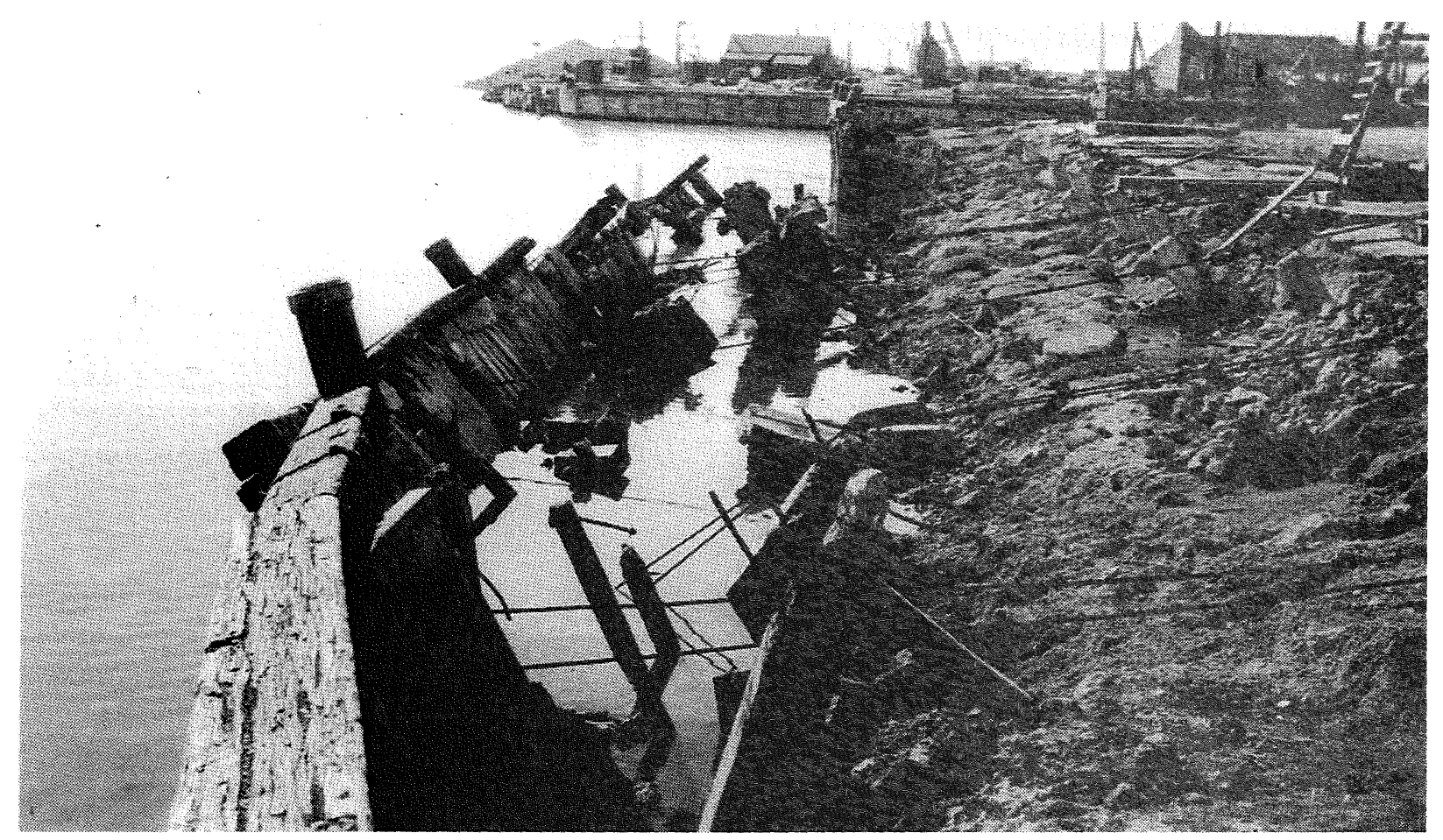

Figure 7: View northwards along failed West Quay at Port Ahuriri, Napier. $\quad$ (Courtesy of the Alexander Turnbull Library, D.H. Jones Collection, Wellington). 
[30], in stressing the importance of having strong bonding mortar, notes that "Even in those cases where cement mortar had been used the sand was of a quality to reduce materially the strength of the result. The bricks, too, had never been wetted and they parted from the mortar as clean as the day they left the brickyard;... It was noticeable that the upper surfaces of the bricks sometimes had mortar adhering to them, but rarely the lower surfaces." This is a subtle point relating to the actual bond achieved by the cement mortar to the bricks (as well as its own internal strength), when assessing earthquake risk URM buildings.

As noted earlier some brick buildings in the Hastings/Napier area suffered little damage. An example is the two-storeyed Burton Brewery in Hastings, as illustrated in Figure 9(b), which evidently was protected by the presence of reinforced concrete ring beams. It lost an unbraced brick parapet, but otherwise suffered only minor cracks.

\section{Steel Framed Buildings}

There were not many fully steel-framed buildings in Hawke's Bay in 1931. Furkert [9] notes that there was "no instance of a steel-framed building collapsing, although the brick and masonry work surrounding the steel frames were frequently much shattered." Brodie and Harris [8] stated that many of the timber-clad warehouses for wool at Port Ahuriri in Napier had structural steel (RSJs) beams and columns supporting the second floor, and were extensively damaged due to inadequate internal bracing. However, it seems that these buildings mostly did not gain their lateral resistance from steel frames. One that may have done so is illustrated in Fig. 10.

\section{Reinforced Concrete Buildings}

Within the MM8 isoseismal there was quite a number of buildings structured in reinforced concrete, the approximate numbers in selected towns being: Waipukurau 7, Wairoa 15 , Hastings $>19$ and Napier $>55$. By 1931 reinforced concrete was being used quite often for non-domestic buildings, as a cost-competitive alternative to brick. Concrete beam and column construction was common, as were large structural concrete walls (often party walls), while the cladding of such buildings was usually of unreinforced brick construction. Most reinforced concrete buildings were one or 2-storeyed, while there were at least 133 -storeyed reinforced concrete buildings in the Hastings/Napier area and a few in Wairoa at the freezing works. One of these buildings that performed very well (although it was a "comer building") is illustrated in Figure 11(a), namely the 3-storey Hannah's Building in Napier, which despite being gutted by fire was restored and was used for another 65 years (demolished in 1996). The least successful reinforced concrete building was the Nurses' Home at Napier Hospital (Figure 11(b)) which collapsed completely (its volume loss was $100 \%$ ). This was the only concrete building (out of a total of c.70 in the MM10 zone) in which casualties were caused by structural damage.

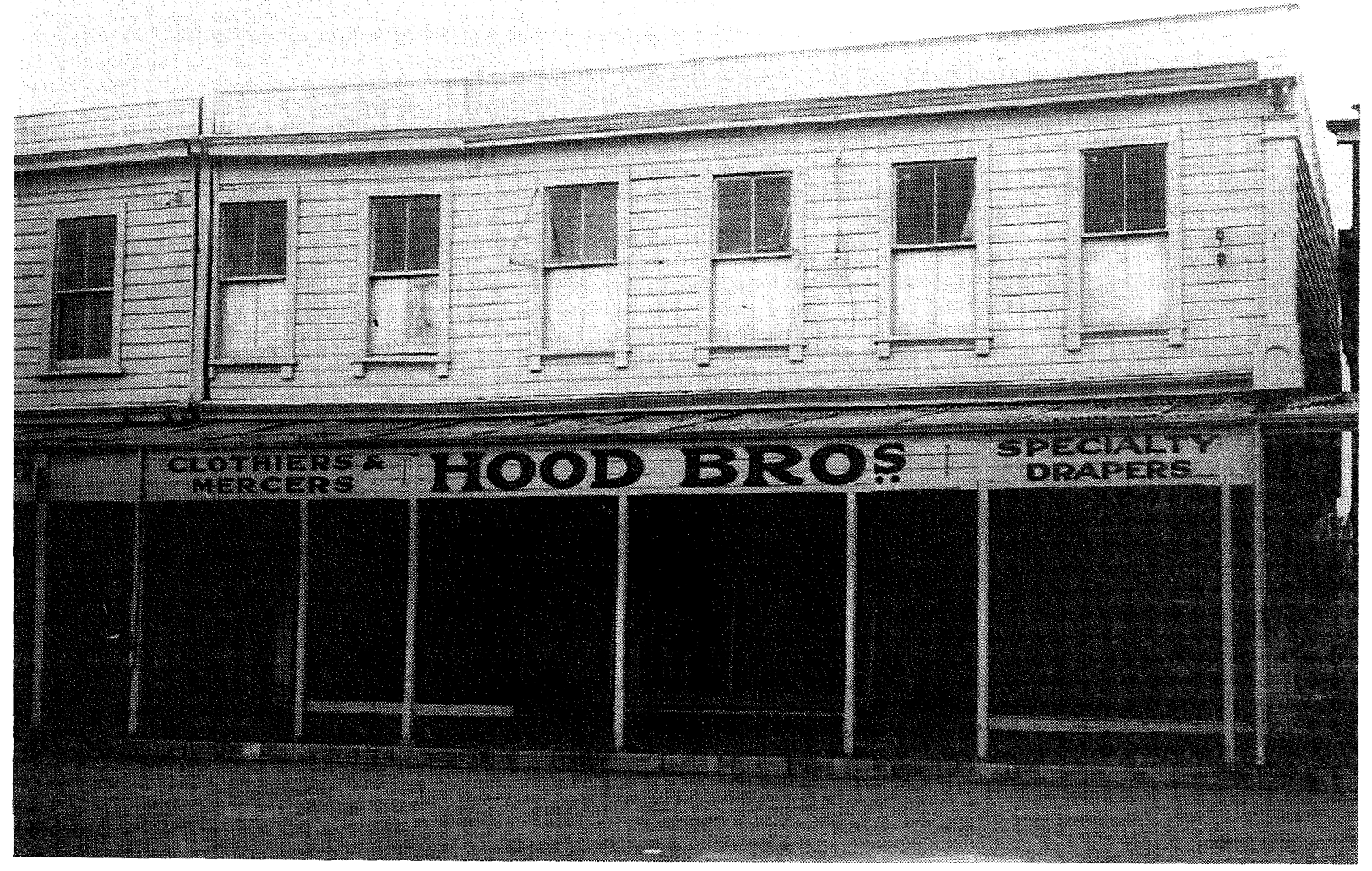

Figure 8: Example of racking destroying plate glass windows in the weak front wall of shops built of timber. Hood Brothers, Waipawa, in the MM8 zone. (Courtesy of the Alexander Turnbull Library, Insurance Council of New Zealand Collection, Wellington). 


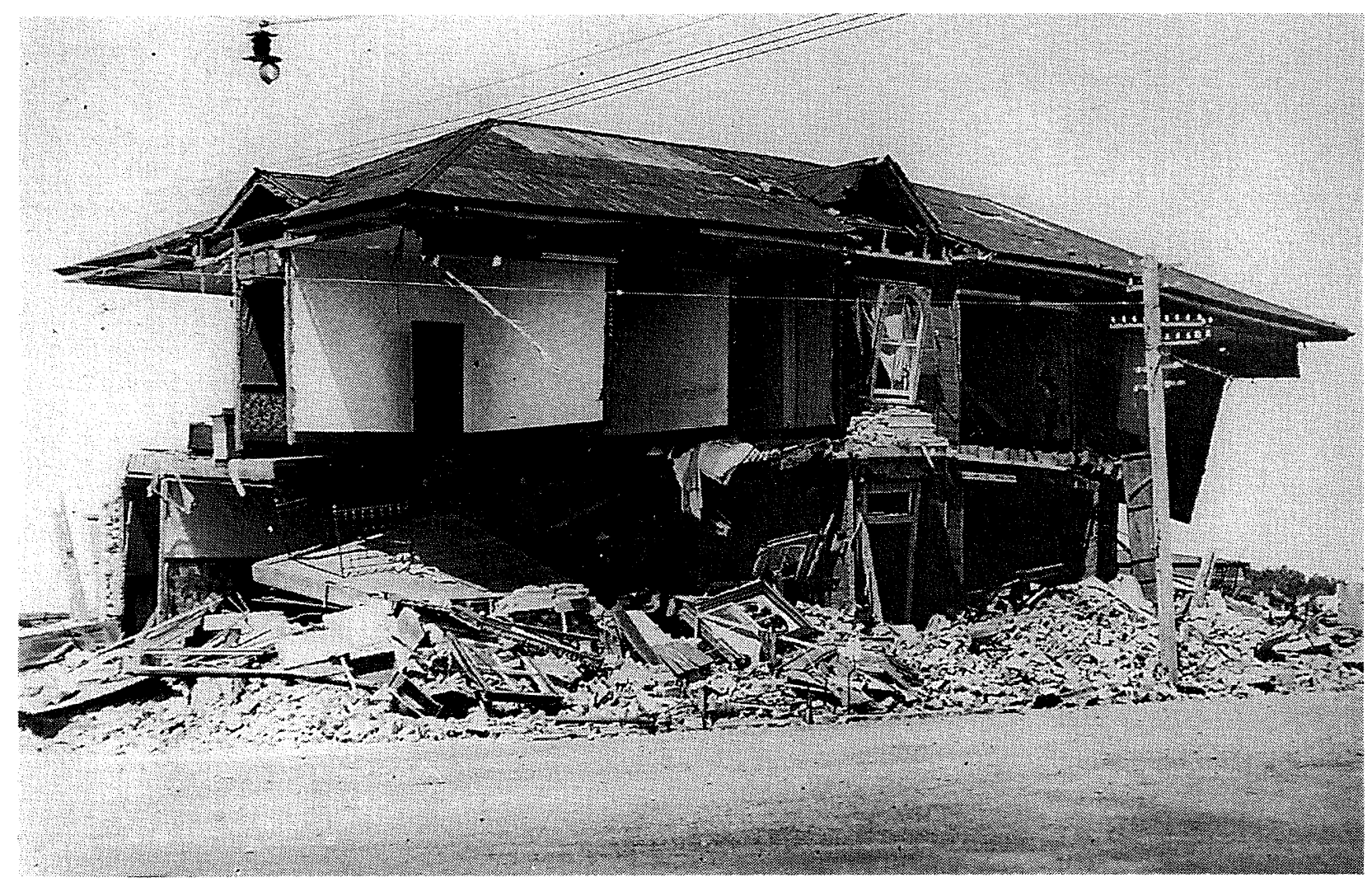

Figure 9: (a) A poor brick building. The Taradale Hotel illustrating two weaknesses in brick construction: (i) external brick walls not fixed to partitions; (ii) weak mortar (cleanly separated bricks). (Courtesy of the Alexander Turnbull Library, Insurance Council of NZ Collection, Wellington).

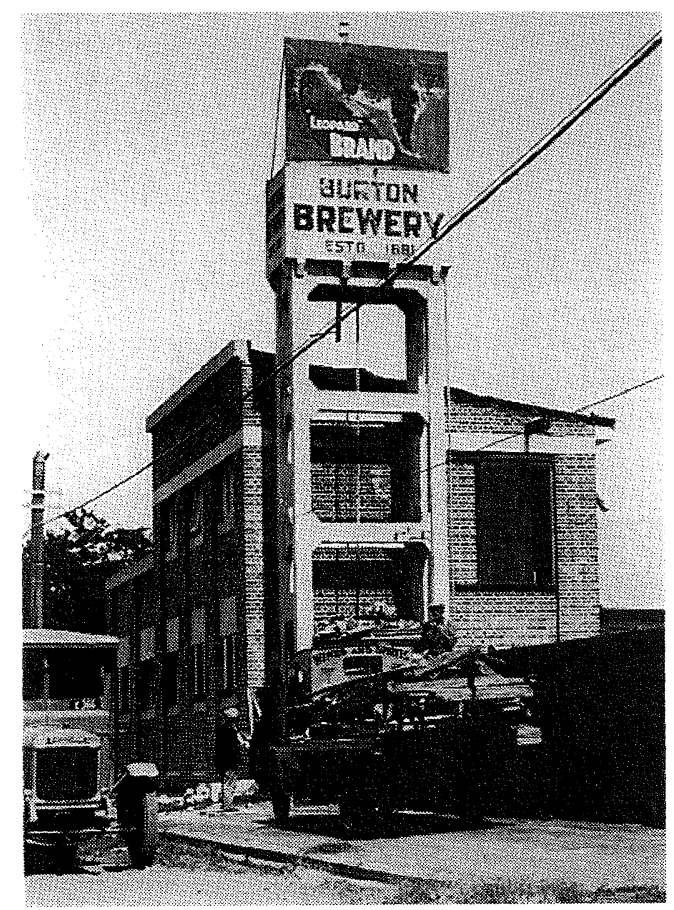

Figure 9: (b) A successful brick building. The Burton Brewery, Hastings. (Courtesy of the Alexander Turnbull Library, Insurance Council of NZ Collection, Wellington). 


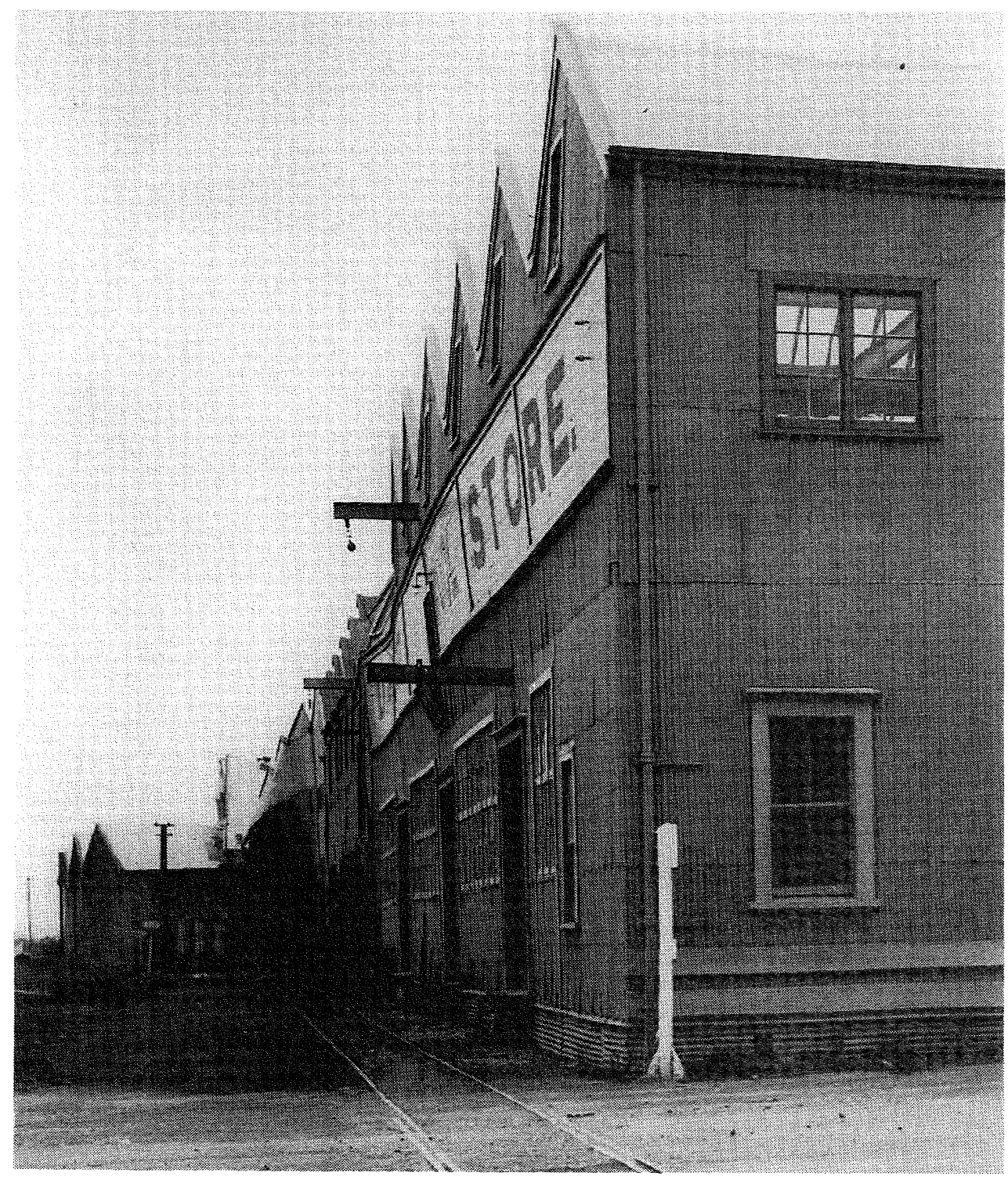

Figure 10: Dalgety's No. 2 Store, Port Ahuriri, Napier one of the few steel-framed buildings in the region, was inadequately braced. (Courtesy of the Alexander Turnbull Library, Insurance Council of NZ Collection, Wellington).

Contemporary reports by engineers $[8,30]$ remarked on the generally good performance of reinforced concrete buildings. The following six comments are paraphrased versions of points made by Brodie and Harris [8]:

1. Foundations: These comprised either spread footings or raft foundations (associated with buildings with basements), and both types proved satisfactory. [Apparently piles were not then being used for reinforced concrete buildings in the Napier/Hastings area.]

2. Columns. Most of the damage observed in reinforced concrete buildings occurred in the columns, particularly in the bottom storey. Additional strength was desirable for the junction of columns and beams.
3. Beams. Only one instance [was found] of any evidence of beam failure. The main defects were inadequate bearings and inadequate anchorage at wall-columns.

4. Concrete Curtain Walls. $100 \mathrm{~mm}$ thick curtain walls reinforced with $6 \mathrm{~mm}$ rods horizontally and vertically at 300 to $450 \mathrm{~mm}$ centres were undamaged.

5. Partition Walls. Where integral reinforced concrete walls had been used, very little trouble occurred, bu brick partition walls, in many cases were damaged.

6. Shop Fronts. The glassed area insisted on by the owners necessitated sacrificing lateral rigidity in the front of the building, the disastrous result being well illustrated in many shops. 


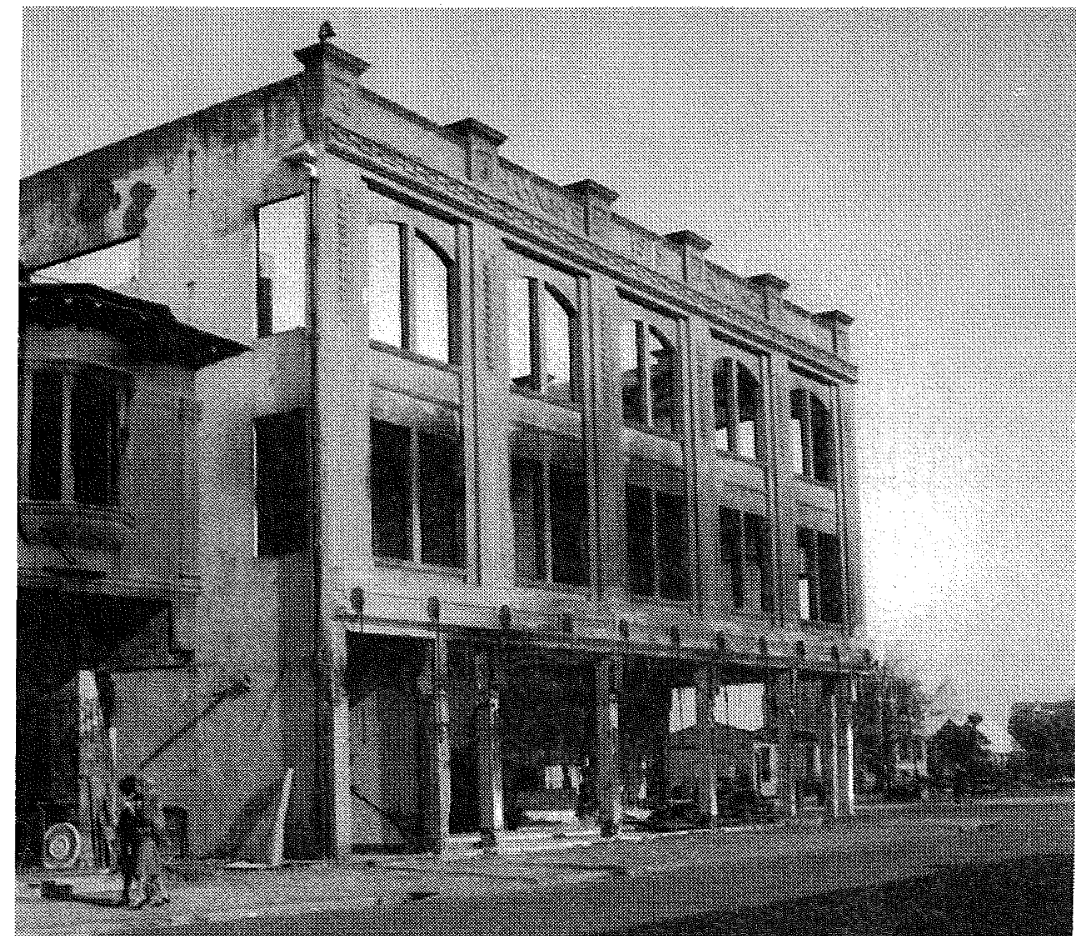

Figure 11: (a) A successful reinforced concrete building. Hannah's shoe shop, Napier, a "corner building", MRF + concrete block infill. (Courtesy of the Alexander Turnbull Library, Wellington).

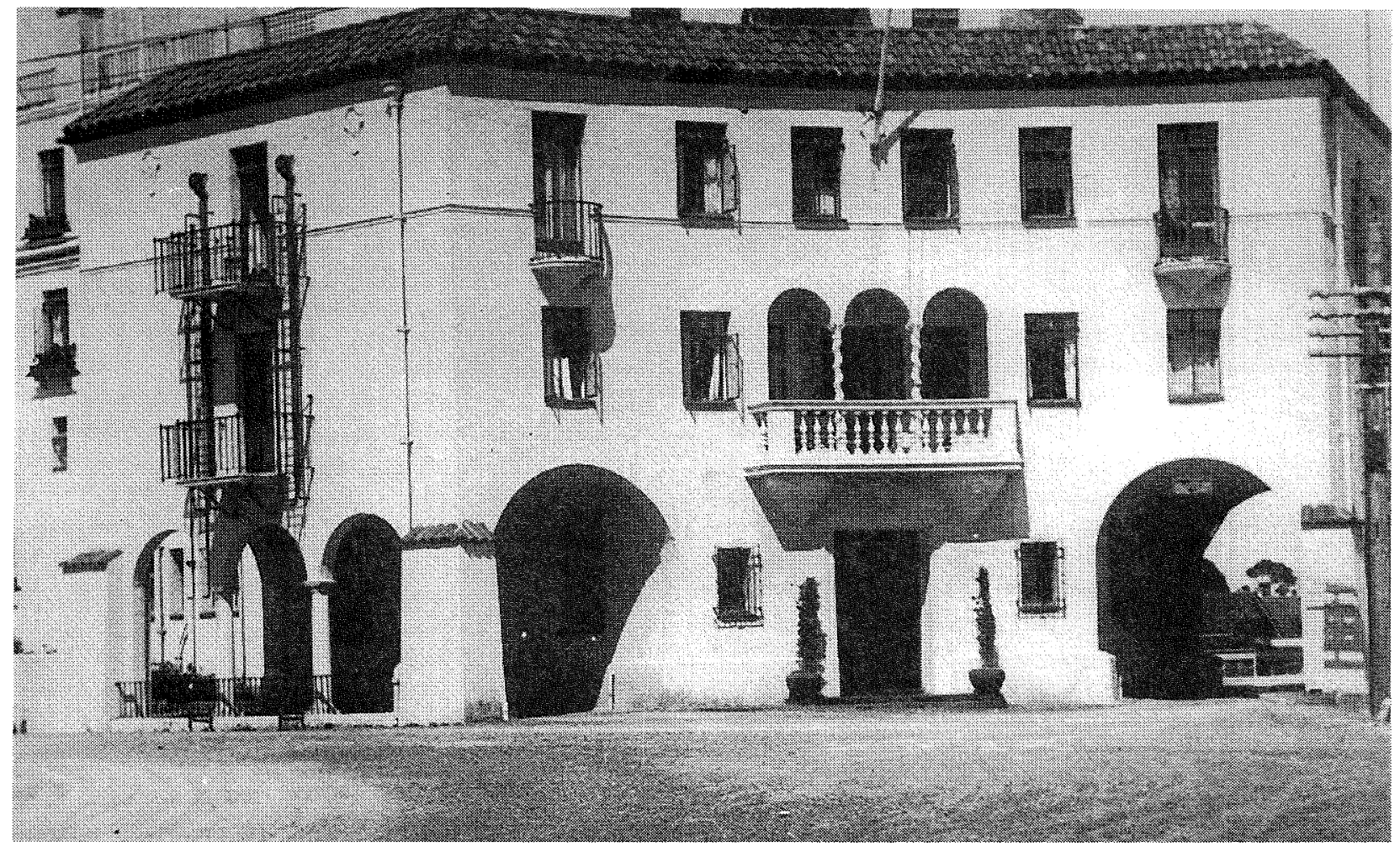

Figure 11: (b) A poor reinforced concrete building. The Nurses' Home at Napier Hospital before the earthquake, the only r.c. building to collapse completely, due to a bottom storey weakened by large openings and little reinforcement (Courtesy of the Alexander Turnbull Library, Wellington). 
Some further valuable comments, derived from Mitchell [30], are:

$$
\text { Construction using mushroom head columns, flat }
$$$$
\text { slab and drop panels survived the earthquake almost }
$$$$
\text { without flaw. }
$$

$$
\text { "Numerous" buildings of plain beam and column }
$$
construction were practically unharmed.

$$
\text { Some of the most successful buildings were those in }
$$
which reinforced concrete and brick were suitably combined (i.e. r.c. frames with brick infill).

Interpreting the above comments by Brodie \& Harris and Mitchell in the light of the present review of the concrete buildings, it should be noted that few, if any, were of purely beam and column construction. External walls except shop fronts were either solid walls or had "wide columns" between window openings (eg. Figure 10), and masonry infill was much used (eg. on the off-street facades of Hannah's building, Figure 11(b). The detailing of reinforcement was extremely primitive and inadequate in relation to 1990's standards. Concrete was weak, reinforcing bars were smooth, laps were short and diameters were small. It therefore appears that the concrete buildings fared well because they had adequate area of walls to cope with the horizontal shear forces.

The performance of "corner buildings" is of particular interest. None of the 12 such buildings ( 2 and 3 storeyed) suffered from this form of asymmetry, in fact it is more likely that they were saved from collapse by the presence of structural walls (even brick infill) on two orthogonal perimeter facades. This observation is limited to buildings of up to three storeys, and is not necessarily in conflict with the poor behaviour of high-rise corner buildings in other earthquakes. This difference may be explained by the fact that low-rise buildings will have much smaller roof level torsional displacements than high-rise buildings.

\section{"Well-Built" Buildings}

With the growing awareness of the need to deal with existing "unsafe" ("brittle") buildings, not only pre-code [32], but also post-code [33] buildings, the high value of learning about the earthquake resistance (strengths and weaknesses) of older buildings from past earthquakes is obvious. To this end, the factors contributing to buildings being "well-built" as learned from the 1929 Murchison earthquake were listed in a study of that earthquake by the author [2]. The lessons from that earthquake were limited by the small number of non-domestic buildings inside the MM9 isoseismal, so we now have the opportunity to review those findings with the benefit of observing many brick and reinforced concrete buildings from the Hastings/Napier area.

The present studies generally confirm the findings of the study of the Murchison earthquake, but in relation to masonry (i.e. brick) buildings, three extra criteria for "well-built" have been observed, namely:
- $\quad$ Adequate area of spread footings where buildings are founded on soft ground.

- $\quad$ Effective bond of mortar to bricks.

- If brickwork is reinforced (e.g. by steel mesh strips in mortar bedding every 8th-10th course) then extra rating points are deserved.

- For reinforced concrete buildings of up to 3 storeys, structural walls on two adjacent perimeter facades ("corner buildings" may suffice as well as symmetrical wall arrangements.

The full list of factors from the previous study [2], as revised above, for timber, masonry, and composite masonry and timber buildings, is given here in Appendix $\mathrm{A}$. The most common attribute of well-performing concrete buildings (particularly brittle ones) is to have ample structural walls (sometimes brick infill between concrete columns was sufficient). A full appraisal of such buildings will be given by the present author in a forthcoming paper, a progress report on which has been included in a recent paper [34]

\section{THE FIRES FOLLOWING THE EARTHQUAKE}

The Hawke's Bay earthquake is the only New Zealand earthquake so far to result in major conflagrations. The fires in Napier greatly increased the damage to non-domestic property. Shortly after the main shock, fires broke out in business areas of Napier and Hastings and spread widely. In Napier's main commercial area, fires broke out in three chemist shops $[10,12]$, where bunsen burners were in close proximity to highly flammable materials [24]. One of these fires was put out, but the fire brigade failed to control the other two because the mains water supply soon failed and a brisk breeze sprang up about an hour after the main shock. In Napier, major fires also spread through part of the industrial area in the suburb of Port Ahuriri.

In Hastings, the brick fire station was completely wrecked and it was some time before the fire engines could be got out from under the debris. Eventually this was done and the fires which had started were soon well under control. This was in part due to the fact that a stand-by diesel generator at the Hastings power house was able to restore power to the artesian water supply pumps one and a half hours after the main shock [10]. According to the Jubilee book of Hastings Intermediate School: "The [fire]men were attending to places that had been on fire and watching for further outbreaks when another shock came at $8.45 \mathrm{pm}$ and the whole water system was put out of action. A fire immediately started where the Grand Hotel [had collapsed] and the brigade was powerless to stop the big fire; the only equipment they had was the first aid [?] plant and this was kept working all night, keeping the buildings on the other side of the street cool. In this way they were successful after a strenuous night's work. Next day the water supply was restored again and any further [fire] outbreaks were quickly dealt with."

The ground shaking had caused damage in the burnt out areas of Napier ranging from slight to destroyed, as shown by the photographs taken before the fires took over by the professional photographer A. B. Hurst. 
The ground area, of the buildings and their yards, but excluding the streets, over which buildings were burnt out were approximately:

Napier commercial:

Port Ahuriri:
$86,000 \mathrm{~m}^{2} \quad$ (eight complete town blocks, plus large parts of three others, Figure 12) $21,000 \mathrm{~m}^{2} \quad$ (one complete town block plus, about half of each of three others)
Hastings:

$9,000 \mathrm{~m}^{2} \quad$ (parts of three town blocks)

The boundaries of the above burnt out areas were determined by the present author, partly by a study of post-fire photographs, and also by comparison with contemporary maps from two sources $[28,35]$ both of which were found to be not entirely accurate. Some buildings in the "burnt out" area were hardly damaged structurally from either shaking or fire, notably three substantial 3-storey reinforced concrete buildings, the "E\&D" building [30], the new Post Office and Hannah's building, all of which were refurbished and reoccupied.

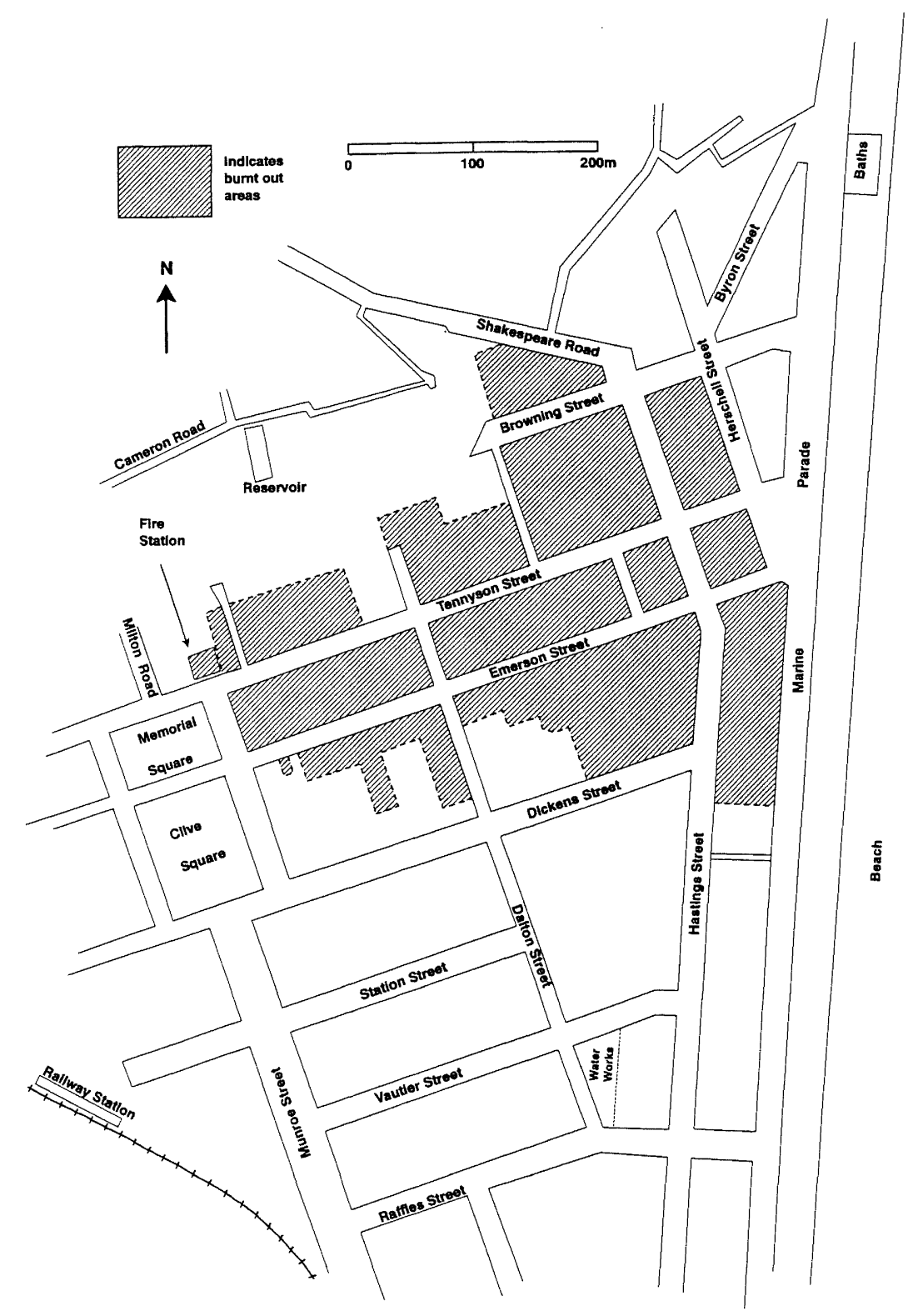

Figure 12: Map of the commercial centre of Napier showing the area gutted by the major earthquake-induced fire. 


\section{INTENSITIES}

Intensities were assigned in accordance with the 1996 New Zealand version of the Modified Mercalli intensity scale proposed by Dowrick [17]. While generally consistent with the 1992 New Zealand intensity scale [16], the 1996 proposals deal with some deficiencies in the 1992 scale in relation to precode categories of construction discovered during a study of the 1929 Murchison earthquake [2], as well as improving the references to chimney damage and elaborating the definitions of the highest intensities (MM10-12). The criteria for MM8MM10 given by Dowrick [17] are included here in Appendix B.
Higher intensities, i.e. $\geq$ MM8, have been found for a total of 64 localities. This large number of high intensity assignments is nearly twice what it would otherwise have been because of the discovery by the author of archival material recording details of damage to rural houses in Hawke's Bay County. Many of these rural houses had water tanks on stands which fell in the earthquake, a criterion for intensity of MM8 (or greater). In addition, some of the houses fell off their piles or were badly racked, indicating MM9, e.g. at Putorino and Te Pohue. This information helped greatly in defining the extent of the MM9 region, particularly in the sparsely populated rural areas to the north, west and south of Hastings and Napier (Figures 13, 14). Additional similar information on intensity was found in Jubilee books of many small schools which existed in the hill-farming country in those days.

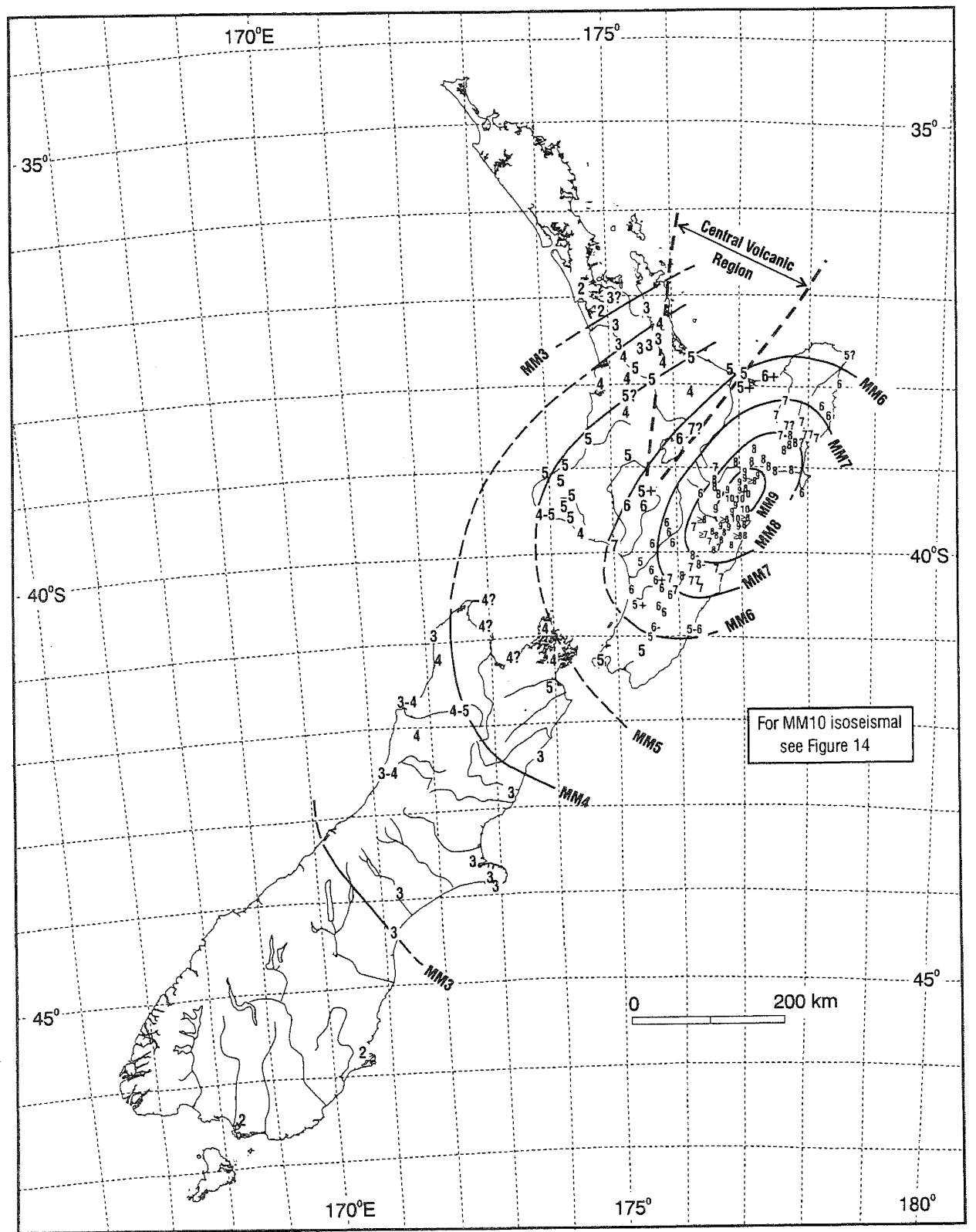

Figure 13: Map showing Modified Mercalli intensity observations and isoseismals of the 1931 Hawke's Bay earthquake, as assigned in this study. 


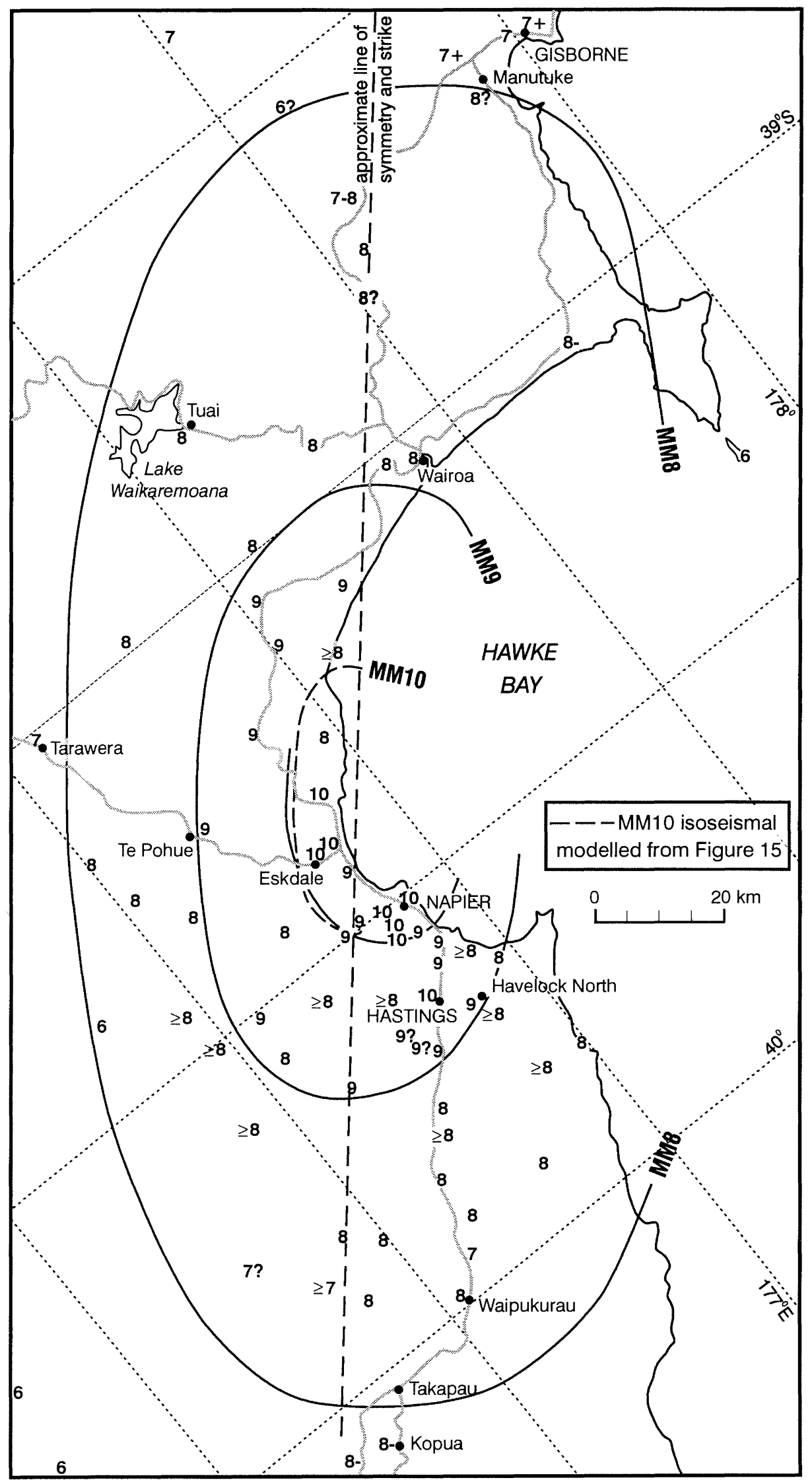

Figure 14: Map showing inner isoseismals and MM intensities in the 1931 Hawke's Bay earthquake, including an MM10 isoseismal modelled from Figure 15. 
As the higher intensities are of the most engineering interest, the derivations of intensities of MM8 and greater are now discussed for the four largest towns involved, namely Waipukurau, Wairoa, Napier and Hastings. An intensity in square brackets at the end of each subheading, e.g. [MM8], is the intensity indicated by that subset of entries. For Waipukurau and Wairoa, individual buildings are named. Numbers in brackets after each building, e.g. (2), indicate the number of storeys, and the following abbreviations are used: $\mathrm{RC}=$ Reinforced Concrete; $\mathrm{BI}=$ Brick Infill

\section{INTENSITY IN WAIPUKURAU}

Information relating to intensity is as follows:

\section{Bldgs Type III, damaged in some cases [MM7-8]}

Partial collapse: None. Damaged: Ford Motors (1) post and lintel reinforced concrete, a few cracks in brick infill, and part of one brick parapet fell. Undamaged: Sowry \& Dowrick/Timms workshops (1), reinforced concrete, brick, and timber. Hospital (2), reinforced concrete. Winlove's shop $(1,2)$, RC. Salvation Army Hall (1) reinf. conc (poss brick?). Central H. B. Press (1), brick with partial concreting beam. There were one or two more undamaged buildings which were probably Type III.

\section{Bldgs Type II, damaged in some cases [MM8]}

Partial collapse: None. Damaged: Blom's shop (2), party wall parapet fell. H. B. Farmers shop (1), cracked. Municipal Theatre (2), cracked. Tavistock Hotel (2), one 2nd floor wall fell out, otherwise little damage. Undamaged: Dairy factory (1), Dalgety's shop (1), Primary School (1), High School (1), Leigh's Building (shop) (2), Nurses Home (2), Public Trust Office (2), Salvation Army Hall (1), St Mary's Church, St Joseph's School. There were several more undamaged Type II commercial buildings.

Bldgs Type I (all external walls masonry), damaged [MM7] Post Office (2+ tower) Clock tower and part of parapet fell into street (in use till c.1990). McConchie's Bldg (2), shop with soft-storey frontage, cracked (still in use 1994)

\section{Bldgs Type I (composite brick and timber) undamaged [MM6] \\ Undamaged: Power Board (1).}

Timber Buildings [ $<\mathrm{MM} 9]$

Most homes were of timber, damage to which was light, generally restricted to that associated with chimneys.

Industrial Brick Chimney Stacks [MM8]

Chimney stacks at the Dairy Factory and Sanatorium fell.

Bridges, no damage [<MM9]

Multispan timber railway and road bridges across the Tukituki River were both undamaged.

Summarising the above Waipukurau data, it is seen that the following criteria for the intensity reaching at least MM8 were fulfilled.
- $\quad$ Bldgs Type III (Masonry B) damaged in some cases: (1 damage, $\geq 5$ undamaged)

- Bldgs Type II (Masonry C) damaged with partial collapse: (4 damaged, no genuine partial collapse, $>10$ undamaged)

- Industrial chimney stacks bought down: (2 fell).

There is no evidence for MM9 in Waipukurau, particularly because: Bldgs Type III were not seriously damaged, Bldgs Type II did not completely collapse, Bldgs Type I were not destroyed, houses did not fall off their piles, the two Tukituki River bridges suffered no damage, and no other MM9 criteria were reported. Hence the intensity in Waipukurau is assigned as MM8.

\section{INTENSITY IN WAIROA}

Information relating to intensity is as follows:

Bldgs Type III, damaged in some cases [MM8]

Partial Collapse: None. Damaged: Osler's Bakery, Kabul St (1) RC $+\mathrm{B}$, brick walls fell. Sandeman \& Sommerville/Union Bank (1) RC? slight cracks. Wairoa Farmers Co-op Meat Co. (Freezing Works): several RC bldgs, some 3 storeys, possible slight structural damage. Wairoa Flaxmills (1) RC, heavy damage but in use until the September 1932 Wairoa earthquake.

Undamaged: Andresen's drapery (2) RC. Bank of NZ (1) probably RC (demolished with difficulty c. 1990). Grandstand at Lambton Square, RC. Shop (Henley's fruiterer in 1993) (1) $\mathrm{RC}+\mathrm{BI}$. Wairoa Borough Council Chambers (1) RC. Wairoa Co-op Dairy (2) RC + BI. Wairoa Fire Brigade (1) RC.

Bldgs Type II, damaged in some cases [MM8].

Damaged: Clyde Hotel (2) part of rear wall, or garage, fell Nurses Home (2), front facade fell. Undamaged: Bank of Australasia (2), Bldg in Locke St (McDonald's lawyers in 1993) (1), Corkill's Ironmongery (2), St Joseph's Infant School (1), New Wairoa Hotel (2), Wairoa Power House (1), Wairoa Meat Co. (2), Wairoa Fish Ltd (1993 name) (1). In addition there were three (only) brick houses, all undamaged.

Bldgs Type I, damaged, some partially collapsing [MM8] A substantial proportion of the brick commercial buildings in Wairoa, mostly in Marine Parade, had little earthquake resistance in the front facade, either in-plane or out-of-plane, many facades collapsing. Example of these are: Anderson's Country Garage (1), Duco Motor Service (1), Fletcher's boot shop (1), Gaiety Picture Theatre, (2), Gilberd's Men's Outfitters (1), Gillespie Chemist (1), Hanham's Booksellers (1), Hannah's/Pidduck's shops (1), Johanson's Hardware (1), Kent's Drapery (?), Osler's Bakery (2), Raffol's shop (1), Ritter's Tearooms (?), Sheehan's Pastrycook (1), Sweetman Drapery (1), Cullens \& Cooks/Carroll's (?). The damage to some of the shops was worsened by the collapse of brick party walls, a few involved in a short series of adjacent shops in a domino effect.

The Post Office ( $2+$ tower), suffered the collapse of its heavy clock tower, (compare similar buildings in the MM8 zone of the 1929 Murchison earthquake [3]). 
Undifferentiated Bldgs Types I and II, some damaged [MM8] There were perhaps a dozen further brittle buildings (either Type I or II) in Wairoa, some damaged, some not. These included two houses and St John's Church (at Te Uhi) of unreinforced hollow concrete blocks, all of which collapsed.

\section{Timber Buildings [ $<\mathrm{MM} 9]$}

Damage to timber buildings was mostly confined to that associated with chimneys. Few, if any fell off their piles, and no obvious rocking occurred. Two timber buildings on piles on the river's edge (Loan \& Mercantile, and Williams \& Kettle) were badly damaged by the ground spreading laterally towards the river.

\section{Brick Industrial Chimney Stack [MM8]}

The Freezing Works chimney stack fell.

\section{Domestic Water Tanks [MM8]}

Some elevated tanks at houses outside of the borough fell.

\section{Monuments at cemetery, many fell [ $\geq \mathrm{MM} 8]$}

Summarising the above Wairoa intensity data, the evidence suggests MM8, and less than MM9. Hence, the intensity for Wairoa is assigned as MM8. In the above analysis of the damage it is seen that serious damage (partial collapse) was confined to buildings classified as Type I. This is supported by a detailed letter of 14 February 1931 to C.E. Adams (The Chief Seismologist), from a Wairoa solicitor, G.O.K. Sainsbury, who remarked that "the ruined buildings were mostly more or less jerry built. My own brick office, one storey high, suffered no damage whatsoever, and this is also the true of other faithfully built structures - even of brick - in the town."

\section{INTENSITY IN HASTINGS AND NAPIER}

Because of their locations near to the inferred fault plane (Figure 2), both Hastings and Napier are likely to have experienced intensities of $\geq \mathrm{MM} 9$. For evaluating such high intensities the criteria used here relate entirely to the damage to buildings. All of the buildings were low-rise, the highest being of 5 storeys. As the earthquake occurred before the advent of earthquake resistant design in New Zealand, non-timber buildings were "brittle", and of Types I-III of the MM intensity scale (defined here in Appendix B). Most of these three types of building in Hastings and Napier were non-domestic in nature.

In the borough of Napier there were about 650 non-domestic buildings. Evidence of the effects of ground shaking on many (c.130) of these buildings was obliterated by the major fires which swept through two parts of the main commercial and industrial zones. Of the remaining c.520 non-domestic buildings, it has been possible to establish the overall effects of shaking on about 360 of them.

In Hastings there were about 420 non-domestic buildings. For only 11 of these buildings was evidence of shaking damage destroyed by post-earthquake fires. Of the remaining c. 410 buildings it has been possible (so far) to establish the overall effects of shaking on about 255 of them.
In the following assignments of MM intensity, the definitions used for the damage states were those discussed elsewhere [17], ie "collapse" (complete) and "partial collapse" correspond to volume losses of $\geq 50 \%$ and $<50 \%$ respectively. "Destroyed" includes buildings with no volume loss, but severe cracking leading to subsequent demolition.

For Napier, information relating to intensity is as follows:

\section{Napier Bldgs Types I and II, most destroyed [MM10]}

Of the available sample of about 100 buildings, only four were essentially undamaged. About two thirds of the buildings collapsed partially or completely, while the remainder were mostly cracked sufficiently to be condemned. In addition there were about 21 brick houses in Napier, of which nine are known to have collapsed completely [5], while some suffered no damage [8].

Napier Bldgs Type III, some heavily damaged, some collapse [MM10]

Of the available sample of 61 Type III buildings, one collapsed completely, one partially collapsed, 26 suffered cracking (some of these also had fallen parts), and 33 suffered only slight damage. The buildings which performed well were those with ample concrete walls.

Napier "Well-built" Timber Buildings, some moderately damaged [MM10]

Of the available sample of 214 non-domestic timber buildings, one collapsed completely, two partially collapsed, 78 were moderately damaged, and 133 suffered only slight (or zero) damage. The distribution of damage to timber houses [5] was similar to that for non-domestic buildings.

From the above Napier data it is concluded that the intensity in Napier was MM10.

For Hastings, information relating to intensity is as follows:

Hastings Bldgs Types I and II, most destroyed [MM10] Of the available sample of 142 Types I and II buildings, only six appear to have been essentially undamaged. About threequarters of the buildings collapsed partially or completely, while the remainder were mostly cracked sufficiently to be condemned.

Hastings Bldgs Type III, some heavily damaged, some collapse [MM10]

Of the available sample of 36 Type III buildings, five collapsed partially or completely, 15 suffered cracking (some of these also had fallen parts), and 14 suffered only slight damage. The buildings which performed well were those with ample concrete walls.

Hastings Well-built Timber Buildings, some moderately damaged [MM10]

All the evidence supports the conclusion that no timber buildings collapsed completely. Of the available sample of 79 non-domestic buildings, two partially collapsed, four suffered moderate damage and 71 suffered only slight damage. As in Napier [5], timber houses performed well [11], despite "many" coming off their piles [36], much chimney destruction [36] and 
some racking.

From the above Hastings data, it is concluded that the intensity in Hastings was MM10.
The damage to non-domestic buildings in Hastings and Napier, briefly summarised above, is the subject of a detailed study which will be described in a forthcoming paper, preliminary findings of which have recently been described [34].

Table 2: $\quad$ MM intensities assigned at various locations in the 1931 Hawke's Bayearthquake

\begin{tabular}{|c|c|c|c|c|c|c|c|}
\hline Location & MMI & Location & MMI & Location & MMI & Location & MMI \\
\hline \multicolumn{8}{|l|}{ North Island } \\
\hline Arapaonui & 8 & Makomako & $6 ?$ & Porangahau & 7 & Waipawa & 7 \\
\hline Arapuni & 5 & Mangaweka & 6 & Portland Island & 6 & Waipiro Bay & 6 \\
\hline Ardkeen & 8 & Manutuke & $8 ?$ & Poukawa & 8 & Waipukurau & 8 \\
\hline Argyll & 8 & Maraekakaho & 9 & Pukekohe & 2 & Wairakei & $7 ?$ \\
\hline Auckland & 2 & Maraetotara & $\geq 8$ & Puketapu & 9 & Wairoa & 8 \\
\hline Awakino & 5 & Martinborough & 5 & Puketitiri & 8 & Waitahora & $7 ?$ \\
\hline Awanui & $9 ?$ & Marton & 5 & Putorino & 9 & Waitara & 5 \\
\hline Bay View & 9 & Masterton & 6 & Raetihi & $6+$ & Waitoa & 3 \\
\hline Bridge $\mathrm{Pa}$ & $9 ?$ & Matamata & 4 & Rangiwahia & 6 & Waiwhare & $\geq 8$ \\
\hline Cambridge & 5 & Matamau & 7 & Rangoroa & $6-$ & Wakarara & 7 \\
\hline Carterton & 5 & Matata & 5 & Rere & $7 ?$ & Wallingford & 7 \\
\hline Castlepoint & $5-6$ & Matawai & 7 & Rissington & 8 & Wanganui & 7 \\
\hline Clevedon & $3 ?$ & Motu & 7 & Rotorua & 4 & Weber & 7 \\
\hline Clive & 9 & Mercer & 3 & Sherenden & 9 & Wellington & 5 \\
\hline Crownthorpe & 8 & Mohaka & 9 & Springhill & $\geq 7$ & Whakatane & 5 \\
\hline Dannevirke & 7 & Morrinsville & 3 & Stratford & 5 & Whakatu & 9 \\
\hline East Cape & $5 ?$ & Motea & 7 & Taihape & $6+$ & Whangarei & 0 \\
\hline Eketahuna & 6 & Napier & 10 & Tangoio & 10 & Woodville & 7 \\
\hline Elsthorpe & 8 & New Plymouth & 5 & Tarawera & 7 & & \\
\hline Eltham & 5 & Ngaruawahia & 3 & Taradale & 10 & South Island & \\
\hline Eskdale & 10 & Nireaha & 6 & Taumaranui & 5 & & \\
\hline Feilding & 6 & Norsewood & $8-$ & Tauranga & 5 & Akaroa & 3 \\
\hline Fernhill & $\geq 8$ & Norsewood & $8-$ & Taupo & 6 & Akaroa Heads & 3 \\
\hline Foxton & 6 & Nuhaka & $8-$ & Te Aroha & 3 & Ashburton & 3 \\
\hline Gisborne & $7+$ & Ohakune & $6+$ & Te Aute & 8 & Blenheim & 5 \\
\hline Greenmeadows & 10 & Okawa & $\geq 8$ & Te Awamutu & 4 & Cheviot & 3 \\
\hline Hamilton & 4 & Ongaonga & 8 & Te Awanga & 8 & Christchurch & 3 \\
\hline Hangaroa & $7-8$ & Opapa & $\geq 8$ & Te Hapara & 7 & Dunedin & 2 \\
\hline Hastings & 10 & Opotiki & $6+$ & Te Karaka & 7 & Farewell Spit & $4 ?$ \\
\hline Haumoana & $\geq 8$ & Opunake & $4-5$ & Te Kuiti & 4 & French Pass & 4 \\
\hline Havelock North & 9 & Otamauri & $\geq 8$ & Te Mata & $\geq 8$ & Greymouth & $3-4$ \\
\hline Hawera & 5 & Otane & 8 & Te Pohue & 9 & Invercargill & 2 \\
\hline Hopelands & $7 ?$ & Otorohanga & $5 ?$ & Te Reinga & $8 ?$ & Kahurangi Pt & 3 \\
\hline Horopito & $5+$ & Paeroa & 4 & Te Teko & $5+$ & Kaikoura & 3 \\
\hline Huanui & 6 & Pahiatua & 6 & Thames & 3 & Karamea & 4 \\
\hline Hunterville & 6 & Pakaututu & 8 & Tikokino & 8 & Murchison & $4-5$ \\
\hline Inglewood & 5 & Pakipaki & 9 & Tiniroto & 8 & Nelson & $4 ?$ \\
\hline Kawhia & 4 & Palmerston North & $6+$ & Tolaga Bay & 6 & Picton & 4 \\
\hline Kaiwaka & 9 & Patea & 4 & Tuai & 8 & Reefton & 4 \\
\hline Kereru & $\geq 8$ & Patoka & 8 & Turiroa & 8 & Takaka & $4 ?$ \\
\hline Kopua & $8-$ & Patutahi & 7 & Tutira & 9 & Timaru & 3 \\
\hline Kuripapango & 6 & Petane Valley & 10 & Waiaruhe & 8 & Westport & $3-4$ \\
\hline Kotemaori & 9 & Pihanui & 8 & Waikari & $\geq 8$ & & \\
\hline Levin & $5+$ & Poraite Hills & 9 & Waimarama & 8 & & \\
\hline
\end{tabular}




\section{ISOSEISMALS}

The local intensities assigned in this study (Table 2) and the isoseismals derived therefrom are plotted on Figures 13, for the complete set, while the higher intensities are shown in more detail on Figure 14. While both the length and width of the MM9 isoseismal are quite well constrained, an important feature of these maps is the small number of observations of MM10. This is partly due to the fact that about half of the shallow portion of the fault rupture surface was offshore (by about $10 \mathrm{~km}$ ), according to the model on Figure 2, and partly due to the absence of the best potential indicators of MM10, ie. brittle buildings, in the rural region north of Napier.

It is thus not possible to draw a complete well-supported MM10 isoseismal based on local observations of intensity of MM10. There is clearly space on Figures 13 and 14 for a complete MM10 isoseismal, and its approximate dimensions may be inferred by extrapolation from the MM4-MM9 isoseismals inwards to the isoseismal centroid, where the maximum intensity is assumed to be almost MM11. As shown in Figure 15, this procedure results in estimated overall dimensions of approximately $40 \mathrm{~km} \times 18 \mathrm{~km}$ for the MM10 isoseismal. As the overall pattern of isoseismals is fairly symmetrical, this conjectural isoseismal has been plotted (Figure 14) symmetrically inside the MM9 isoseismal. This conjectural MM10 isoseismal is seen to fit the plotted observations quite well, and is located within $\pm 1 \mathrm{~km}$ of the partial MM10 isoseismal drawn by the author in the conventional manner.

It is noted that the most important inner isoseismals, MM9 and MM10, have mean radii which are $75 \%$ and $45 \%$ respectively of those of Eiby's preliminary map [15] which, like that of the Murchison earthquake [2], was based on very inadequate data. It is interesting to compare the pattern of the isoseismals (Figure 14) with the pattern of equal peak ground accelerations (PGAs) predicted for an oblique fault dipping at $45^{\circ}$ by Midorikawa [37] (Figure 16), which shows that the centre of strongest shaking is on the up-dip side of the rupture. In the present case it is obviously not possible to fully verify this through the damage pattern, because of the absence of data in the offshore zone. However the contour patterns of the empirical intensities and the theoretical PGAs match quite well. Note that the direction of rupture in the 1931 event is not known, nor is the exact rupture surface. Midorikawa's PGA values are very high, but the pattern is sound.

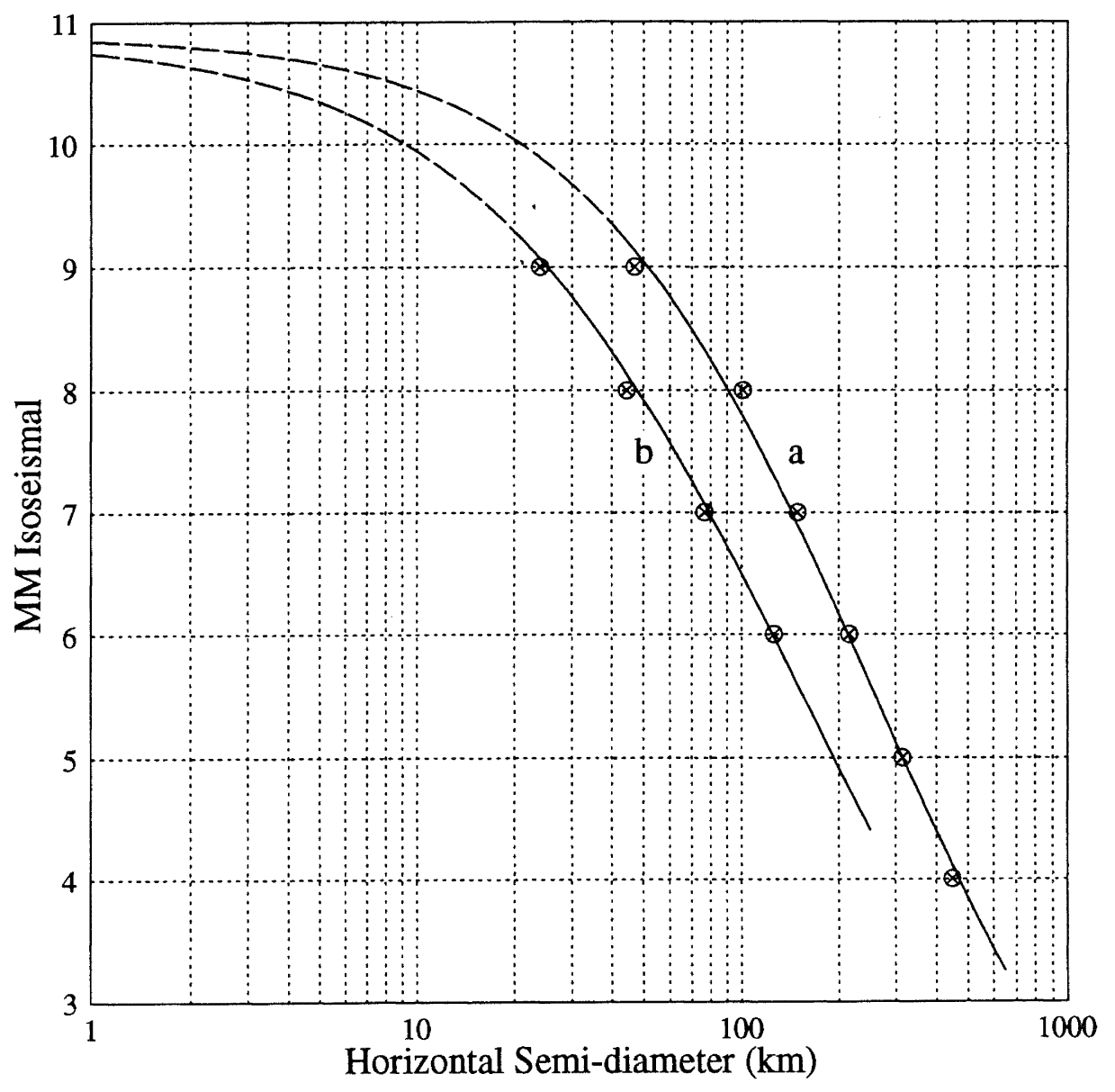

Figure 15: Plot of intensity (MM4-MM9) against semi-diameter (km), along-strike (a) and normal to strike (b), with extrapolation to MM10 and the geometric centre of isoseismal pattern. 


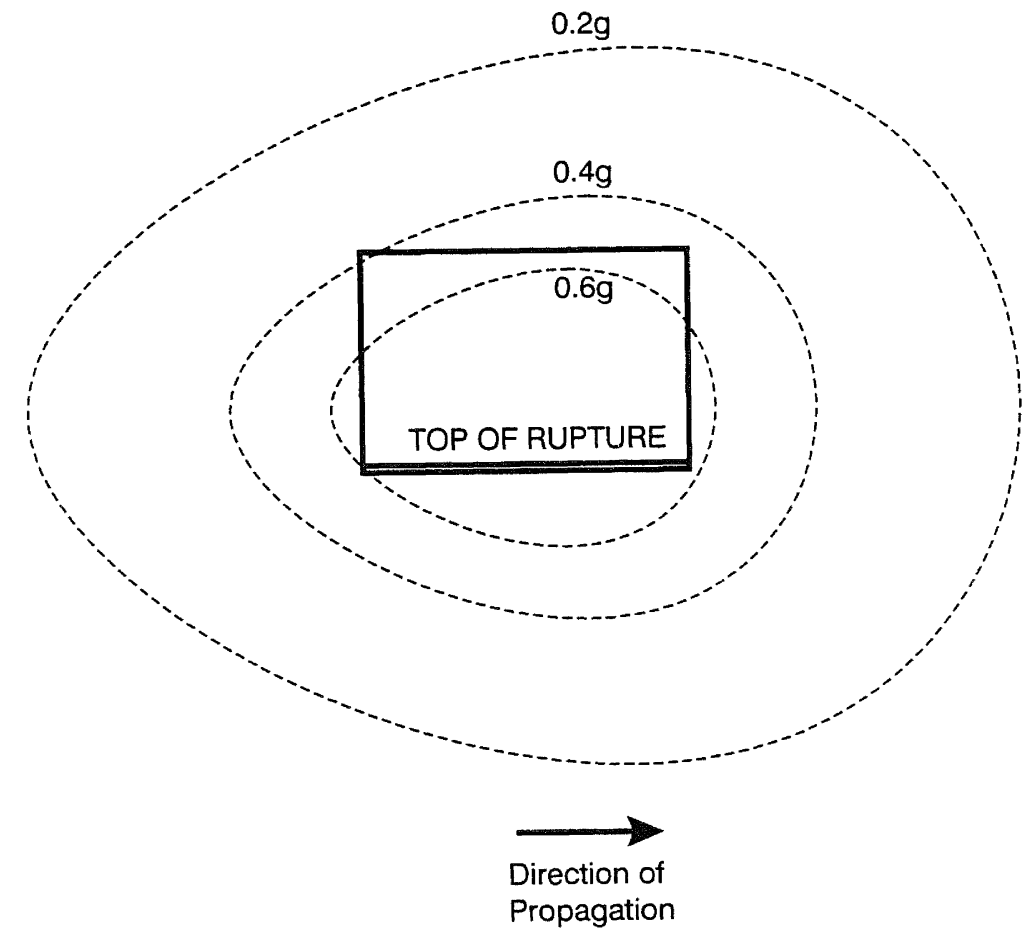

Figure 16: Model of contours of PGA for a 450 dipping thrust fault earthquake of $M_{w}{ }^{7}$, adapted from Midorikawa [36], showing pattern of stronger shaking on up-dip side of rupture plane. Compare pattern with Figure 14.

An interesting far-field feature of Figure 14 is the cramping in of the MM3-MM5 isoseismal to the north-west of the Central Volcanic Region (CVR), which is consistent with the high attenuation of the CVR as noted elsewhere, eg. Zhao etal [38].

\section{CONCLUDING REMARKS}

As a result of this study of this large pre-code 1931 earthquake, the following observations are made:

1. The substantial existing body of contemporary written and photographic documentation, supplemented by living memories, has permitted the assembly of a good picture of the damage and intensities caused by New Zealand's most damaging historical earthquake. Intensities were assigned for 172 localities, 40 percent more than for next best the documented event (Murchison, 1929), [2].

2. The MM9 and MM10 isoseismals encompass only $55 \%$ and $20 \%$ of the areas of the corresponding isoseismals of the previous preliminary map of this event drawn by Eiby [15].

3. In the stronger shaken region (intensities MM8 or more), many buildings performed very well, despite not being designed for earthquake resistance. In particular, concrete and timber buildings in the MM10 zone mostly suffered slight to moderate damage only, while nearby good quality brick buildings were destroyed.

4. Of the c.70 reinforced concrete non-domestic buildings which experienced ground shaking intensity MM10 (ie in Hastings and Napier), only one was damaged so as to cause casualties, despite all of them being brittle. The safe performance of these buildings resulted from the use of ample structural walls, made either of concrete, or with the use of brick infill.

5. For buildings of up to 3 storeys, structural walls limited to two on adjacent perimeter facades ("corner buildings") may protect buildings as well as symmetrical wall arrangements.

6. The characteristics of "well-built" buildings of various materials have been better defined. Existing well-built low-rise pre-1976 reinforced concrete buildings in general do not need to be retrofitted for earthquake resistance. This finding should be made use of in codes for retrofitting of brittle concrete buildings.

7. The criterion relating to Buildings Type III for MM10 in the Modified Mercalli intensity scale [17], should be adjusted to allow for the better than expected performance of walled brittle concrete buildings.

8. Much damage was done to lifelines (ie roads, railways, bridges, wharves, and systems for electricity, water, gas, telephones and sewerage) in the near source area (intensity $\geq$ MM9). The damage to lifelines was usually most severe in areas of weak or liquefiable ground.

9. Much information exists on the methods used and times required for restoring lifeline services, both partially and fully. 
10. The loss of water supply in Hastings and Napier had severe disabling consequences on their fire brigades, so that the earthquake induced fires considerably increased the loss of life and property in both those towns, especially Napier.

\section{ACKNOWLEDGEMENTS}

This study was funded by FRST under Contract No. Co5405. The author wishes to acknowledge the many people who helped bring this study to fruition, particularly $J$ and $M$ Swan, G Archibald and M Barrett (all of Wairoa), J Axford and G McGahan (Hawke's Bay Cultural Trust, Napier), R and H McGregor (Art Deco Trust, Napier), G Natusch (Architect, Napier), J Sullivan and J McCracken (Alexander Turnbull Library, Wellington), A Jones (Waipukurau).

Thanks are due to the external reviewer, D D Spurr, and also to my colleagues $P$ N Davenport and G L Downes for constructive reviews.

\section{REFERENCES}

1. Dowrick, D. J., and Rhoades, D. A., Magnitudes of New Zealand earthquakes (in prep).

2. Dowrick, D. J. (1994), Damage and intensities in the magnitude 7.8 1929 Murchison New Zealand, earthquake, Bull. NZ Natl. Soc. Earthq. Eng., 27(3), 190-204.

3. Haines, A. J., and D. J. Darby (1987), Preliminary dislocation models for the 1931 Napier and 1932 Wairoa earthquakes, N.Z. Geological Survey Report EDS114.

4. Hull, A. J. (1990), Tectonics of the 1931 Hawke's Bay earthquake, New Zealand Journal of Geology and Geophysics, 33, 309-320.

5. Dowrick D .J., D. A. Rhoades, J. Babor and R. D. Beetham (1995), Damage ratios for houses and microzoning effects in Napier in the magnitude 7.8 Hawke's Bay, New Zealand earthquake of 1931, Bull. NZ Natl. Soc. Earthq. Eng., 28(2), 134-145.

6. Dixon, C.E. (1931), Earthquake proves superiority of wooden buildings, Part I, NZ National Review, 15 March, 45-58.

7. Dixon, C.E. (1931), Earthquake proves superiority of wooden buildings, Part II, NZ National Review, 15 April, 45-61.

8. Brodie, A., and B.E. Harris (1933), Damage to buildings, part of Report on Hawke's Bay earthquake of 3rd February, 1931, NZ Journal of Science and Technology, XV, 108-114.

9. Furkert, F.W. (1933), The effect of earthquakes on engineering structures, Minutes of Proceedings of the Institution of Civil Engineers, 236, 344-368.
10. Robinson, I. R. and H. L. Benjamin (1932-3), Effects of earthquakes on electrical supply systems, Proc. New Zealand Society of Civil Engineers, XIX, 256-289.

11. Baird, H.F. (1931), The Hawke's Bay earthquake of 3rd February, 1931, Unpublished reconnaissance report, Christchurch Magnetic Observatory.

12. Callaghan, F.R. (1933), The Hawke's Bay Earthquake General description, NZ Journal of Science and Technology, XV, 3-38.

13. Adams, C. E., M.A.F. Barnett and R. C. Hayes (1933), Seismological report of the Hawke's Bay earthquake of 3rd February, 1931, NZ Journal of Science and Technology, XV, 93-107.

14. Richter, C.F. (1958), Elementary seismology, W.H. Freeman \& Co., San Francisco.

15. Downes, G.L. (1995), Atlas of isoseismal maps of New Zealand earthquakes, Institute of Geological and Nuclear Sciences, monograph 11, Lower Hutt, New Zealand.

16. Study Group of NZNSEE (1992), A revision of the Modified Mercalli seismic intensity scale, Bull. NZ Natl. Soc. Earthq. Eng., 25(4), 345-357.

17. Dowrick, D.J. (1996), The Modified Mercalli intensity scale - Revisions arising from recent studies of New Zealand earthquakes, Bull. NZ Natl. Soc. Earthq. Eng., 29(2), 92-105.

18. Henderson, J. (1933), The geological aspects of the Hawke's Bay earthquakes, NZ Journal of Science and Technology, XV, 38-75.

19. Marshall, P. (1933), Effects of earthquake on coast-line near Napier, NZ Journal of Science and Technology, XV, 79-92.

20. Hancox, G.T., N.D. Perrin and G.D. Dellow (1997), Earthquake induced landsliding in New Zealand and implications for $\mathrm{MM}$ intensity and seismic hazard assessment, Institute of Geological and Nuclear Sciences, Client Report 43601B.

21. Fairless, G. J., and J. B. Berrill (1984), Liquefaction during historic earthquakes in New Zealand, Bulletin $N Z$ National Society for Earthquake Engineering, 17(4), 280291.

22. - Hawke's Bay - Before and After the great earthquake of 1931 - An historical record, The Daily Telegraph Co. Ltd, Napier, New Zealand (1931).

23. Conly, G. (1980), The Shock of ' 31 - The Hawke's Bay earthquake, A.H. \& A.W. Reed Ltd, Wellington, New Zealand.

24. McGregor, R. (1989), The great quake, Regional Publications Ltd, Napier, New Zealand. 
25. Smith, R.T. (1933), Wairoa River bridge, Proc. NZ Soc of Civil Engineers", XX, 140-177.

26. Grayland, E. (1957), New Zealand disasters, A.H. \& A.W Reed, Wellington.

27. Fussell, P.M. (1988), Napier in 1931, Historical Review, Bay of Plenty Journal of History, Whakatane District Historical Society, 36(1), 30-52.

28. Council of Fire and Accident Underwriters Associations of New Zealand - Official records of Napier earthquake, February 3rd-10th 1931, Location No. PA1:f:145.

29. Ford, C.R., Album of photographs of 1931 Hawke's Bay earthquake, Architecture Library, University of Auckland, New Zealand.

30. Mitchell, A.S. (1931), The effects of earthquakes on buildings and structures, NZ Institute of Architects Journal, December, 111-117.

31. Dowrick, D.J., and D.A. Rhoades (1996), Inferences for design, insurance and planning from damage evaluation in past New Zealand earthquakes, Journal of Earthquake Engineering, 1 (1), 77-91.

32. Study Group of NZNSEE (1995), Draft guidelines for the assessing and strengthening of earthquake risk buildings, New Zealand National Society for Earthquake Engineering.

33. Study Group of the NZNSEE (1996), The assessment and improvement of the structural performance of earthquake risk buildings, Draft for general release, New Zealand National Society for Earthquake Engineering.

34. Dowrick, D. J. (1998), Earthquake risk for property and people in New Zealand, Proceedings NZ National Society for Earthquake Engineering Conference, Wairakei, 43-50.

35. Butcher, H. F. (1931), General description of the NapierHastings earthquake, 3rd February, 1931, Community Planning, 1(3), 86-39.

36. Boyd, M.B. (1984), City of the Plains - A history of Hastings, Victoria University Press for the Hastings City Council.

37. Midorikawa, S. (1993), Semi-empirical estimation of peak ground acceleration from large earthquakes, Tectonophysics, 218, 287-295.

38. Zhao, J.X., Dowrick, D.J. and McVerry, G.H (1997), Attenuation of peak ground accelerations in New Zealand earthquakes, Bull. NZ Natl. Soc. Earthq. Eng., 30(2), 133157.
APPENDIX A: Criteria for "well-built" buildings, arising from studies of earthquake damage to pre- code buildings

\section{Timber Buildings}

- $\quad$ Robust piles (cantilevered or framed), or reinforced concrete strip foundations

- Superstructure tied to piles

- Wall openings not too large

- Walls adequately braced, especially in buildings of more than one storey

- Strong chimneys, or few weak ones.

\section{Reinforced Concrete Buildings}

- Use of ample structural walls. For buildings of up to 3 storeys, walls limited to two on adjacent perimeter facades ("corner buildings)" may work as well as symmetrical wall arrangements.

- No weak storeys

- Adequate foundations in soft ground

\section{Masonry Buildings}

- $\quad$ Adequate area of spread footings where buildings are founded on soft ground

- Wall openings not too large, especially no soft-storey effect

- Strong mortar, especially in thin walls

- $\quad$ Effective bond of mortar to bricks

- Bricking through corners

- If brickwork is reinforced (eg by steel mesh strips in mortar bedding every 8th-10th course) then extra rating points are deserved.

- $\quad$ Large buildings to be structurally compartmented

- Gables tied in

- Effective diaphragms, at least at roof level

- No heavy towers or unbraced parapets

\section{Composite Masonry and Timber Buildings}

Many commercial and industrial buildings had some externa walls of timber and some of brick, the brick being used either for fire walls or for creating (relatively) imposing front facades. Such buildings were often built well in non-seismic terms, but suffered seismically from:

(i) the partial soft-storey effect of the openings of large shop windows

(ii) unrestrained parapets and gables, and

(iii) the inherent difficulty of tying brick and timber together adequately.

Despite these drawbacks, many composite masonry and timber buildings suffered little damage at intensity $\geq M M 8$ in either the 1929 Murchison or 1931 Hawke's Bay earthquakes. The criteria for "well-built" composite masonry/timber would be an amalgam of those given above separately for timber buildings and for masonry buildings. 
APPENDIX B:

Extracts from the Modified Mercalli scale [17]. Criteria for MM8-MM10 relevant to pre-code buildings

\section{MM8}

Building Type I, heavily damaged, some collapse.

Buildings Type II damaged, some with partial collapse.

Buildings Type III damaged in some cases.

Monuments and factory stacks twisted or brought down.

Decayed timber piles of houses damaged.

Houses not secured to foundations may move.

Most unreinforced domestic chimneys damaged, some below roof-line, many brought down.

\section{MM9}

Many Buildings Type I destroyed.

Buildings Type II heavily damaged, some collapse.

Buildings Type III damaged, some with partial collapse.

Houses not secured to foundations shifted off.

\section{MM10}

Most Buildings Type I destroyed.

Many Buildings Type II destroyed.

Buildings Type III heavily damaged, some collapse.

Some well-built timber buildings moderately damaged (excluding damage from falling chimneys).

\section{NOTE TO 1996 NZ MM SCALE}

\section{Construction Types:}

Buildings Type I (Masonry D in the NZ 1966 MM scale)

Buildings with low standard of workmanship, poor mortar, or constructed of weak materials like mud-brick or rammed earth. Soft storey structures (eg shops) made of masonry, weak reinforced concrete, or composite materials (eg some walls timber, some brick) not well tied together. Masonry buildings otherwise conforming to Buildings Types I-III, but also having heavy unreinforced masonry towers. (Buildings constructed entirely of timber must be of extremely low quality to be Type I).

\section{Building Type II (Masonry C in the NZ 1966 MM scale)}

Buildings of ordinary workmanship, with mortar of average quality. No extreme weakness, such as inadequate bonding of the corners, but neither designed nor reinforced to resist lateral forces. Such buildings not having heavy unreinforced masonry towers.

\section{Buildings Type III (Masonry B in the NZ 1966 MM scale)}

Reinforced masonry or concrete buildings of good workmanship and with sound mortar, but not formally designed to resist earthquake forces. 